\title{
Detonation nanodiamonds: from synthesis theory to application practice
}

\author{
Valerii Yu. Dolmatov ${ }^{\mathrm{a} \bowtie}$, Alexander I. Shames ${ }^{\mathrm{b}}$, Eiji Ōsawa ${ }^{\mathrm{c}}$, Asko Vehanen ${ }^{\mathrm{d}}$, \\ Vesa Myllymäki ${ }^{\text {, }}$, Alexander O. Dorokhov ${ }^{\mathrm{e}}$, Valerii A. Martchukov ${ }^{\mathrm{a}}$, Anatoly C. Kozlov ${ }^{\mathrm{a}}$, \\ Sergey Yu. Naryzhny ${ }^{a}$, Anastasia Z. Smirnova ${ }^{a}$ \\ ${ }^{a}$ Special Design and Technological Bureau "Technologist", 33-a, Sovetskiy pr., St. Petersburg, 192076, Russian Federation, \\ ${ }^{\mathrm{b}}$ Ben-Gurion University of the Negev, P.O. Box 653, Be'er Sheva 8410501, Israel, \\ ${ }^{\mathrm{c}}$ NanoCarbon Research Institute Limited, Shinshu University, 3-15-1 Tokita, Ueda, Nagano, 386-8567 Japan, \\ ${ }^{\mathrm{d}}$ Carbodeon Ltd. Oy, Vantaa, Pakkalankuja 5, 01510, Finland, \\ e JSC "Plant "Plastics", 12/3, village of Soviets, Kopeysk, Chelyabinsk region, Russian Federation \\ $\bowtie$ diamondcentre@mail.ru
}

\begin{abstract}
The review is devoted to the current state of research and advances in the production and study of the properties of detonation nanodiamonds (DND), their application in technology and medicine. New data on the theory and practice of DND synthesis for the last 1-5 years are considered and systematized. It is shown that the zone of chemical reactions (ZCR) during the blust of explosive materials (EM) is decisive for the fractal pre-diamond structure formation, the final region of the nanodiamonds (1/3-3/4 of the diameter of the explosive charge) formation is determined. The possibility of predicting the DND yield and the influence of parameters on the synthesis process of nanodiamonds from individual EMs of binary and ternary compositions is shown, their optimal formulations are determined. The optimal ZCR width and the existence time of chemical reactions have been identified. The dependence of the DND yield on the nitrogen content in the EM was shown. The most effective method of DND purification and the possibility of obtaining graphite-diamond compositions of a given formulation are presented. The most informative indicators of nanodiamonds characterization are given. The magnetic properties of nanodiamonds are considered and the identity of the properties of DNDs from different EMs is shown. The characteristics of new compositions based on DND are indicated: electrochemical coatings (gold and chromium-diamond), thermal pastes, diamond-containing polymer filaments for a 3D printer, fuel compositions, enterosorbents, compatible with biosystems of the nanodiamond-drug composition.
\end{abstract}

Keywords: detonation nanodiamonds; detonation synthesis; forecasting; DND structure; electronic paramagnetic resonance; electroplated coatings; polymer-diamond composites, fuels; the medicine; 3D printing.

For citation: Dolmatov VYu, Shames AI, Ōsawa E, Vehanen A, Myllymäki V, Dorokhov AO, Martchukov VA, Kozlov AC, Naryzhny SYu, Smirnova AZ. Detonation nanodiamonds: from synthesis theory to application practice. Journal of Advanced Materials and Technologies. 2021;6(1):54-80. DOI: 10.17277/jamt.2021.01.pp.054-080

\section{Детонационные наноалмазы: от теории синтеза до практики применения}

\author{
В. Ю. Долматов ${ }^{a}$, А. И. Шамес ${ }^{б}$, Э. Осава ${ }^{\text {в }}$, А. Веханен ${ }^{\text {, }}$ \\ В. Мюллюмяки ${ }^{\Gamma}$, А. О. Дорохов ${ }^{\text {д }, ~ В . ~ А . ~ М а р ч у к о в ~}{ }^{\mathrm{a}}$, А. С. Козлов ${ }^{\mathrm{a}}$, \\ С. Ю.Нарыжный ${ }^{\mathrm{a}}$, А. 3. Смирнова ${ }^{\mathrm{a}}$ \\ а ФГУП «Специальное конструкторско-технологическое бюро «Технолог», \\ Советский пр., д. 33-а, Санкт-Петербург 192076, Российская Федерация, \\ ${ }^{б}$ Университет им. Бен Гуриона в Негеве, Р.О. Вох 653, Беэр-Шева, 8410501, Израиль,

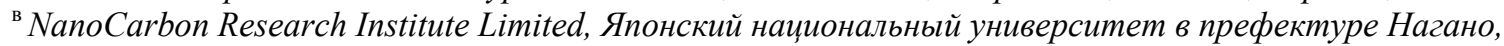 \\ Токита, 3-15-1, Уэда 386-8567, Япония, \\ г Carbodeon Ltd. Oy, Паккаланкуя 5, Вантаa 01510, Финляндия, \\ д $А O$ «Завод «Пластмасс», поселок Советов, 12/3, Копейск, Челябинская область, Российская Федераџия
}

$\triangle$ diamondcentre@mail.ru

Аннотация: Обзор посвящен современному состоянию исследований и достижений в области получения, изучения свойств детонационных наноалмазов (ДНА), их применения в технике и медицине. Рассмотрены и систематизированы новые данные по теории и практике синтеза ДНА за последние 1 - 5 лет. Показано, что зона 
химических реакций (3ХР) при взрыве взрывчатых веществ (ВВ) является определяющей для формирования фрактальной праалмазной структуры, определена окончательная область формирования наноалмазов (1/3-3/4 диаметров заряда ВВ). Показана возможность прогнозирования выхода ДНА и влияние параметров на процесс синтеза наноалмазов из индивидуальных взрывчатых веществ, бинарных и тройных композиций, определены их оптимальные составы. Определена оптимальная ширина ЗХР и время существования химических реакций. Определена зависимость выхода ДНА от содержания азота в ВВ. Приведен самый эффективный способ очистки ДНА и возможность получения графит-алмазных композиций заданного состава. Даны наиболее информативные показатели характеризации наноалмазов. Рассмотрены магнитные свойства наноалмазов и показана тождественность свойств ДНА из различных ВВ. Указаны характеристики новых композиций на основе ДНА: электрохимические покрытия (золото- и хром-алмазные), термопасты, алмазосодержащие полимерные нити для 3D-принтера, топливные композиции, энтеросорбенты, совместимые с биосистемами композиции наноалмазлекарство.

Ключевые слова: детонационные наноалмазы; детонационный синтез; прогнозирование; строение ДНА; электронный парамагнитный резонанс; гальванические покрытия; полимер-алмазные композиты, топлива; медицина; 3D-печать.

Для цитирования: Dolmatov VYu, Shames AI, Ōsawa E, Vehanen A, Myllymäki V, Dorokhov AO, Martchukov VA, Kozlov AC, Naryzhny SYu, Smirnova AZ. Detonation nanodiamonds: from synthesis theory to application practice. Journal of Advanced Materials and Technologies. 2021;6(1):54-80. DOI:10.17277/jamt.2021.01.pp.054-080

\section{Introduction}

The originality of the method for the synthesis of detonation nanodiamonds (DND) lies in the fact that carbon-containing explosive materials (EM) with a negative oxygen balance (OB) are used, in which there is too little oxygen to oxidize the combustible components of the EM.

The properties description of the carbon products of detonation synthesis in traditional terms applied to crystals and diamond powders encounters many limitations and contradictions. With the deepening of DND studies, the dual nature of this material is increasingly manifested: as a nanocrystal of short length on the one hand, and as a self-ordered fractal cluster structure, on the other.

Having undergone the whole complex of shockthermal effects and chemical aggression from the gas medium, detonation carbon appears to us as a substance of the most complex structural organization, including pronounced crystal-like formations, continuously transforming into looser and less ordered spatial formations with a wide range of energy states and types of interatomic and intermolecular bonds. The use of DNDs in various branches of industry and science is stimulated by the need to radically improve the performance properties of composites.

To obtain DND, mixed charges are used, as a rule, of TNT with RDX, in which the optimal parameters for specific power, oxygen balance, charge density and type of shell are selected [1]. However, from a technological and economic point of view, the use of an individual EM would be optimal: there is no need for dangerous and time- consuming stages of crushing and mixing of various explosives, the use of expensive and scarce RDX is excluded. In addition, it is desirable to use a disposable EM having a sufficiently high power and sensitivity to the initiating pulse and giving a significant yield of DND, for example, tetryl (2,4,6-trinitro-N-methyl-N-nitroaniline). Thus, the production of DNDs currently planned for creation at Plastmass Plant JSC (Kopeysk, Chelyabinsk Region) is entirely based on the use of tetril [2].

The DND price is not high, its industrial production has been established and the sales market expansion is forecasted. Nevertheless, DND cannot be classified as a well-studied diamond material, which is explained by the variability of the chemical composition, structure, and, consequently, properties determined by the peculiarities of the synthesis and purification technology from different manufacturers $[1,3-5]$.

The aim of this work is to systematize new empirical and theoretical data obtained in the study of the process of detonation synthesis of nanodiamonds, new studies of the properties of DND and DS, the possibility of their application in industrial technologies and medicine.

\section{Detonation synthesis of nanodiamonds}

\subsection{Theory of DND systhesiz}

The decay of EM is a complex multistage set of sequentially and parallel reactions. During detonation, the chemical equilibrium in the detonation products (DP) does not have time to be established, because the reactions do not go to the 
end; the DP contains more or less intermediate compounds. Experimental determination of the composition of cold DPs does not provide information on the composition of DPs in the Chapman-Jouguet plane (Ch-J), since the composition of DPs changes in the course of expansion and cooling. It was found in [6] that at temperatures above $800 \mathrm{~K}$ the decomposition of all aromatic nitro compounds proceeds predominantly by a radical mechanism.

In the detonation process, mainly diamond nanoparticles with an average size of 4-6 nm have time to form. A defect structure of the diamond phase is formed, in which, along with vacancies in the crystal lattice and broken bonds, there are oxygen, hydrogen and nitrogen atoms included in the form of structural and non-structural impurities, which are predominantly chemically bonded to the surface of particles or are physically retained on it. DND, purified from non-diamond carbon and from the main part of non-carbon impurities, is a powder consisting of aggregates of primary particles of various sizes and different strengths [3, 7-9].

The detonation wave is a single complex of the shock wave, in the front of which the EM decomposition begins, the zone of chemical reactions (ZCR), which follows the shock wave and ends in the Chapman-Jouguet plane, and, finally, the Taylor unloading wave (isentrope). The maximum pressure and temperature are reached inside the ZCR. It was shown in many works [10-14] that the process of nanodiamond formation proceeds in the ZCR and ends at the beginning of the Taylor expansion of detonation products (DP).

The substance inside the ZCR has a velocity approximately equal to the detonation velocity (shock wave velocity $\left.\left(6-8 \mathrm{~km} \cdot \mathrm{s}^{-1}\right)\right)$, and behind the Ch-J plane the mass velocity of gaseous products is much lower and for the studied individual and mixed EMs $\sim 2 \mathrm{~km} \cdot \mathrm{s}^{-1}[9,15,16]$. The flow of matter inside the ZCR is plasma $(T \sim 3000-4500 \mathrm{~K}$ and $P \sim 20-35 \mathrm{GPa})$. After cooling down, DPs consist of $\mathrm{N}_{2}, \mathrm{H}_{2} \mathrm{O}, \mathrm{C}, \mathrm{CO}$, $\mathrm{CO}_{2}, \mathrm{NO}, \mathrm{NO}_{2}, \mathrm{CH}_{4}, \mathrm{O}_{2}, \mathrm{~N}_{2} \mathrm{O}, \mathrm{HCN}$. In the case of detonation of condensed powerful EM, the density of DP in the ZCR significantly exceeds the density of the original explosive $\left(\sim 1.6-1.7 \mathrm{~g} \cdot \mathrm{cm}^{-3}\right)$ and is in the range of $2.2-2.5 \mathrm{~g} \cdot \mathrm{cm}^{-3}$. The release of the energy of the decay process of EM molecules continues beyond the Ch-J plane ( $\sim 20 \%$ of the total explosion energy) [9].

The existence of the DND infrastructure in the ZCR is still controversial. As already noted in [17], the energy for the destruction of all interatomic bonds in EM molecules is not enough, and 4-5 times less than necessary. It is possible that a sufficiently stable formation in the plasma of ZCR is a multiple radicaldimer of carbon with a covalent bond $-\mathrm{C}-\mathrm{C}-$. Moreover, most likely, we can talk not about the crystallization of nanosized diamond in the ZCR (due to the practically absence of heat removal from the formed nanoparticle and the short lifetime of the necessary $P, T$-conditions), but about the process of self-organization of carbon into the condensed phase in accordance with the basic chemical properties carbon atoms, namely, the formation of various types of $\mathrm{C}-\mathrm{C}$ bonds. Consequently, there is a possibility of the occurrence of a fractal carbon network with simultaneous fluctuations of the carbon density in the ZCR. In the "nodes" of this network with the highest density, the carbon condensate has time to more or less form a three-dimensional ordered core, and the regions with a low carbon density are repeatedly destroyed and recombined in the process of AP expansion. Thus, the DND infrastructure can be either a densified plasma-like carbon core, which becomes liquid carbon behind the Ch-J plane, or the formed energetically favorable carbon framework of cyclohexane, which, outside the Ch-J plane, interacting with each other with an even greater decrease in energy, is rearranged into radicalmolecule of adamantane, attacked by radicals $-\mathrm{C}-\mathrm{C}-$ (diffusion mechanism of nanodiamond formation). It is possible that these two mechanisms of DND formation take place. This is followed by crystallization (amorphization) of liquid carbon or cooling of DND crystallites obtained by the diffusion method from the adamantane infrastructure [17].

Figure 1 shows the nucleation and growth of particles of the condensed carbon phase in the ZCR during the expansion of DPs $[18,19]$.

The density, fixed by SAXS, of condensed carbon should be higher than $2.5 \mathrm{~g} \cdot \mathrm{cm}^{-3}$, i.e. higher than the ZCR plasma density. The SAXS signal fixes condensed carbon (without making a distinction between the diamond and non-diamond phases) already in the zone of chemical reactions (ZCR) for TNT, RDX, and TNT-RDX mixtures (70/30; 50/50; 60/40). The response time of the given EM is within $0.1-0.3 \mu \mathrm{s}$, ZCR width - from 0.4 to $1.4 \mathrm{~mm}$. The results of works $[18,19]$ show (see Fig. 1) that the condensed phase of carbon, which has an increased density, appears immediately behind the front of the detonation wave for TNT and TNT-RDX charges. Moreover, the rapid rise of the SAXS signal continues up to $\sim 1.8 \mu \mathrm{s}$. Then there is a kind of plateau - up to $4.4 \mu \mathrm{s}$, and then a slow decline to $15 \mu \mathrm{s}$ and beyond. 


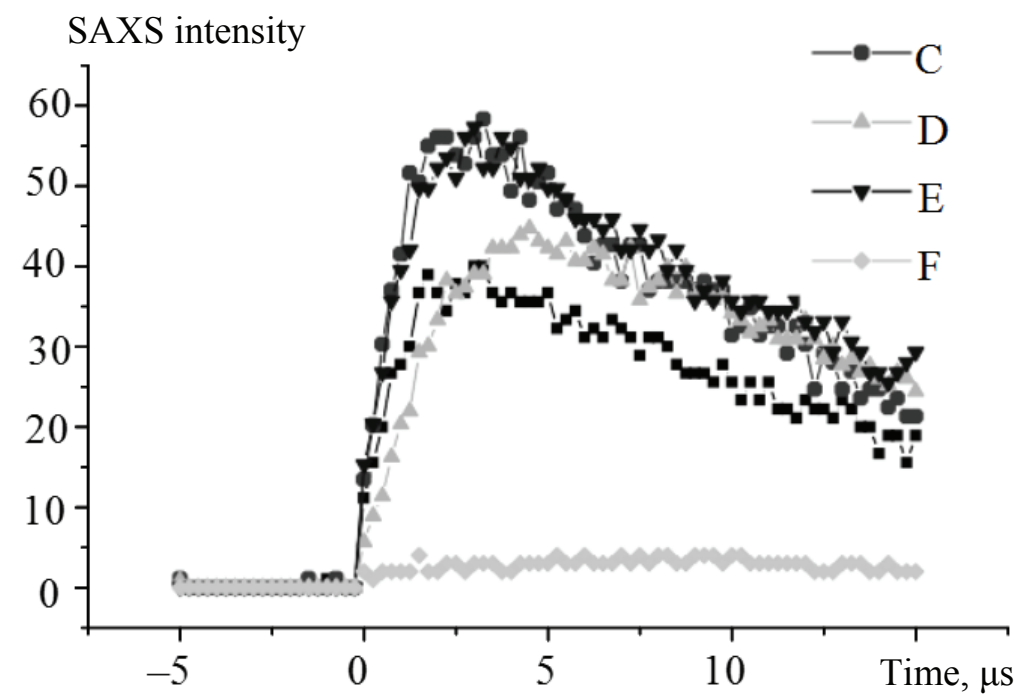

Fig. 1. Small-angle X-ray scattering (SAXS) of the detonation process of condensed carbon-containing EM:

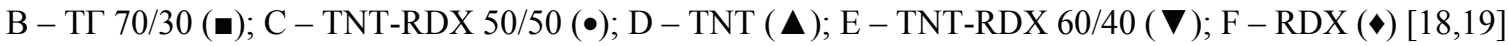

The formation of the DND infrastructure clearly begins in the ZCR, but takes the form of a closely bound diamond-non-diamond carbon structure (DCS) far beyond the ZCR. Calculations show that in $1.8 \mu \mathrm{s}$ the substance traveled a distance of $\sim 4.4 \mathrm{~mm}$, which is $\sim 35 \%$ of the charge diameter, and in $4.4 \mu \mathrm{s}$ $\sim 9.5 \mathrm{~mm}$ ( $77 \%$ of the charge diameter). In fact, this is the zone of DND formation in the form we already know; the process of completion of the formation of DND crystallites occurs at a distance in the range of $1 / 3-3 / 4$ of the charge diameter. Further, there is a sharp drop in pressure and temperature with an attack on the formed nanocarbon, including DND crystallites, corrosive gases $\left(\mathrm{CO}_{2}\right.$ and $\left.\mathrm{H}_{2} \mathrm{O}\right)$, which contributes not only to a decrease in the size of DCS particles, but also to graphitization of DND crystallites.

It is clear that the state of matter in ZCR plasma cannot be described as solid, liquid or gaseous. If we pay attention to the classical diagram of $P, T$-carbon [20], then free carbon from TNT $(P \sim 18 \mathrm{GPa}$, $T \sim 3600 \mathrm{~K}$, DND yield $\sim 1 \mathrm{wt} . \%)$ is clearly not in the state of liquid carbon, but free carbon from BTF (benzotrifuroxane) $(P \sim 36 \mathrm{GPa}, T \sim 4300 \mathrm{~K}, \mathrm{DND}$ yield $\sim 1 \mathrm{wt} . \%)$, on the contrary, falls into the zone of carbon liquid state.

Thus, immediately behind the front of the detonation wave, primary carbon plasmoids are formed in $10^{-8}-10^{-9}$ seconds, which are recorded by the SAXS method. Upon reaching the plateau, i.e. at a distance of $1 / 3-3 / 4$ of the charge diameter, the final formation of a complex DCS structure occurs - inside the DND crystallite, and outside - amorphous carbon formations. A high DND yield is achieved when the formation of free carbon takes $28-35 \%$ of the total carbon in the molecule or mixed EM, or $(20 \pm 2) \%$ of the total carbon for the formation of DND [21]. For the formation of DNDs with a high yield ( $\geq 5$ wt.\%), a ZCR with dimensions of $\sim 0.6 \mathrm{~mm}$ is required, which is a rather large distance. Thus, the following conclusions can be drawn: 1) for the formation of DND, the time of chemical reactions in the ZCR should be within the range of $0.1-0.3 \mu \mathrm{s}$, and the width of the ZCR should be from 0.4 to $1.4 \mathrm{~nm}$;2) the lifetime of a relative plateau for TNT-RDX compositions is from $\sim 1.8$ to $\sim 4.4 \mu \mathrm{s}$, which corresponds to a distance from the detonation wave front of $4.4-9.5 \mathrm{~mm}$ or $1 / 3-3 / 4$ of the charge diameter; 3) a high DND yield (more than 6 wt.\%) is achieved when $(20 \pm 2)$ wt.\% of EM carbon is spent on its formation.

\subsection{DND synthesis practice}

To date, studies of the detonation synthesis of nanodiamonds have revealed the dependence of the yield and quality of DND and DC on the following factors [1, 22-25]: charge composition; specific power of EM; OB; charge density; EM charge shell and its composition; explosive charge modifications (CM); charge forms; composition and heat capacity of the gaseous medium in the explosive chamber (EC); places of initiation of the EM charge; the ratio of the mass of the charge and the volume of the EC; the structure and material of the walls of the EC. The optimal combination of these factors leads to a positive effect.

The armor (shell) of the charge makes it possible to delay the expansion of the DP and, thereby, to complete the chemical reactions in the ZCR as much as possible, providing more time for the formation of 
future DND crystallites, increasing their number $[1,18,19,23]$. When choosing the composition of the EM charge, it is important to proceed from economic factors - to use mass-produced EM, which have a low price. The nomenclature of such individual EM is small and, first of all, it is TNT and RDX. If, in the case of using these individual EM, the yield of DNDs is very low (0.7-0.9 and 0.3-1.0 wt.\%, respectively), then from a mixture of these EM $(\sim 50 / 50)$ DNDs yield is up to $8.2 \mathrm{wt} \% \%$ under optimal conditions of fabrication and detonation. Thus, for the industrial production of DND, it is necessary to have a largescale production of EM or the availability of EM in large quantities at reasonable prices.

\subsubsection{Possibility of nitrogen-free DND obtaining}

An increase in the number of application areas of DNDs may lead to the need to obtain and use nitrogen-free DNDs [22]. For example, DNDs are almost ideally suited as a reflective substance for slow neutrons ( $\mathrm{SN})$ for constructing traps from them [26]. At the same time, it is necessary to first remove some elements - SN absorbers, which include hydrogen, oxygen, chlorine and metal oxides (incombustible impurities). Nitrogen is mainly located inside the DND crystal lattice and its removal is most likely impossible. The ideas presented in [17] about the mechanism of nanodiamond crystallites formation, where the main role is played by multiple $\mathrm{C}-\mathrm{C}$ and $\mathrm{C}-\mathrm{N}$ radicals, show that it is impossible to avoid the explosive flow of nitrogen into a nanodiamond growing by a diffusion method, because in all molecules there is and remains during the decomposition of molecules a dimer with a covalent bond $\mathrm{C}-\mathrm{N}$ (due to lack of energy in the explosion).

In addition, the extremely low yield of DND from RDX $(\sim 0.9$ wt.\%) and from trinitrotriaminobenzene (TNAB) $(\sim 2.0$ wt. $\%)$ instead of $\sim 13$ wt.\% expected by the authors [28] becomes clear. In both cases, all carbon atoms are covalently bonded to nitrogen, although in TNAB this bond competes with the $\mathrm{C}-\mathrm{C}$ covalent bond in the aromatic ring. However, a large number of $\mathrm{C}-\mathrm{N}$ radicals attacking a growing DND particle does not allow the formation of not only nitrogen-free nanodiamonds, but sometimes even nanocrystallite. Here, at least, there are 2 reasons: 1) according to [22], the amount of nitrogen in TNAB is anomalously high (32.6 wt.\%), Which interferes with the formation and growth of the carbon infrastructure of nanodiamond (the optimal range for nitrogen is 23-28 wt.\%); 2) at a TNAB charge density of $1.83 \mathrm{~g} \cdot \mathrm{cm}^{-3}$, most likely, there is an effect of overcompressed detonation, where there is practically no ZCR. The absence of a zone of chemical reactions interferes with the normal nucleation of the DND infrastructure, for which ZCR is clearly required. Thus, the production of nitrogen-free DNDs from commercially available powerful EMs is most likely unrealistic.

The nitrogen content (according to elemental analysis) in DNDs from different manufacturers and obtained in different ways falls within the range of 2.1-2.7 wt.\% [22]. The synthesis conditions and the EM composition have little effect on the nitrogen content in DND. The existence of carbon-containing nitrogen-free EM with the required oxygen balance (OB) $\sim-35 \div-55 \%$ [24] and the required specific power of $30 \div 60 \mathrm{~kJ} \cdot \mathrm{kg}^{-1} \cdot \mu^{-1}$ [29] is unknown. Theoretically, you can use nitroesters, for example, PETN (pentaerythritol tetranitrate) - $\mathrm{C}\left(\mathrm{CH}_{2} \mathrm{ONO}_{2}\right)_{4}$, in which there is no covalent $\mathrm{C}-\mathrm{N}$ bond. The addition of oxygen-free and nitrogen-free organic compounds to PETN up to the recommended $\mathrm{OB}$ would possibly make it possible to obtain nitrogen-free or low-nitrogen DND $(<0.5 \mathrm{wt} . \%)$.

Detonation charges of TNT, RDX, picric acid, tetryl, TNT-RDX $50 / 50$ and TNT-RDX $60 / 40$ is carried out under the same and maximally optimal conditions. The dependence of the DND yield on the content of covalently bound C-N nitrogen in EM molecules has a pronounced peak-like character, and the DND yield of $\sim 2 \mathrm{wt} . \%$ really corresponds to the nitrogen content in TNAB saturated with it. (descending branch of the curve). Thus, in [22], the possibility of purposeful production of nitrogen-free DNDs was considered and an insignificant probability of their production was shown when using nitro compounds with a covalent $\mathrm{C}-\mathrm{N}$ bond; the dependence of the DND yield on the content of nitrogen covalently bound to carbon in EM molecules was defined and the optimal range of nitrogen content was determined from 23 to $28 \mathrm{wt} \%$; the use of nitroesters is recommended to obtain nitrogen-free or low-nitrogen $(<0.5 \%$ nitrogen $)$ DND.

\subsubsection{Predictive estimate of $D N D$ release from individual EM}

In [29], graphs of the dependence of the experimental output of DND on the specific power $\mathrm{EM}$, pressure in the Ch-J plane, detonation velocity $\mathrm{EM}$, and the dependence of the specific power on detonation velocity are presented.

The forecast for the DND yield [21] was carried out according to the EMs given in Table 1 (No. 1-6). These EMs can be of certain interest as possible substitutes for RDX alloys due to the scarcity and high cost of RDX. 
Table 1. Predicted DND yield from explosion parameters [21]

\begin{tabular}{|c|c|c|c|c|c|c|c|c|c|}
\hline \multirow{2}{*}{ No } & \multirow{2}{*}{ EM name* } & \multirow{2}{*}{$\begin{array}{c}Q_{\text {sp }} \\
\text { Specific } \\
\text { power, } \\
\mathrm{J} \cdot \mathrm{kg}^{-1} \cdot \mu \mathrm{s}^{-1}\end{array}$} & \multirow{2}{*}{$\begin{array}{c}\text { The obtained } \\
\text { DND yield, } \\
\text { wt. } \%\end{array}$} & \multirow{2}{*}{$\begin{array}{c}D, \\
\text { detonation } \\
\text { speed, } \\
\mathrm{m} \cdot \mathrm{s}^{-1}\end{array}$} & \multirow{2}{*}{$\begin{array}{c}P_{\mathrm{Ch-J},}, \\
\text { Pressure } \\
\text { in the plane } \\
\text { Ch-J, GPa }\end{array}$} & \multicolumn{4}{|c|}{ Predicted DND yield, wt.\% } \\
\hline & & & & & & by $Q_{\mathrm{sp}}$ & by $P_{\mathrm{Ch}-\mathrm{J}}$ & by $\mathrm{D}$ & Range \\
\hline 1 & TNAB & 44,000 & 2.08 & 7,650 & 29.0 & 6.0 & 4.2 & 6.5 & $4.2-6.5$ \\
\hline 2 & PA & 37,000 & $1.2 * *$ & 7,480 & 26.5 & 5.9 & 5.5 & 5.5 & $5.5-5.9$ \\
\hline 3 & GNAB & 32,000 & 6.63 & 7,311 & 24.6 & 5.2 & 6.1 & 4.4 & $4.4-6.1$ \\
\hline 4 & BTF & 80,000 & No data & 8,610 & 36.0 & 1.5 & 1.5 & 1.5 & 1.5 \\
\hline 5 & Z-TACOT & 30,000 & 3.34 & 7,250 & 26.3 & 4.9 & 5.6 & 4.0 & $4.0-5.6$ \\
\hline 6 & TNB & 32,600 & No data & 7,300 & 20.8 & 5.3 & 3.0 & 43.0 & $4.3-5.3$ \\
\hline
\end{tabular}

* 1,3,5-triamino-2,4,6-trinitrobenzene (TNAB); 2,4,6-trinitrophenol (picric acid (PA)); bis (2,4,6trinitrophenyl)-diazine (GNAB); benzotrifuroxan (BTF); 2,4,8,10-tetranitro-5H-benzotriazolo-(2,1-4)benzotriazoli-6-um (Z-TACOT); 1,3,5- trinitrobenzene (TNB)

** In PA charge $7.7 \%$ water, density $1.49 \mathrm{~g} \cdot \mathrm{cm}^{-3}$.

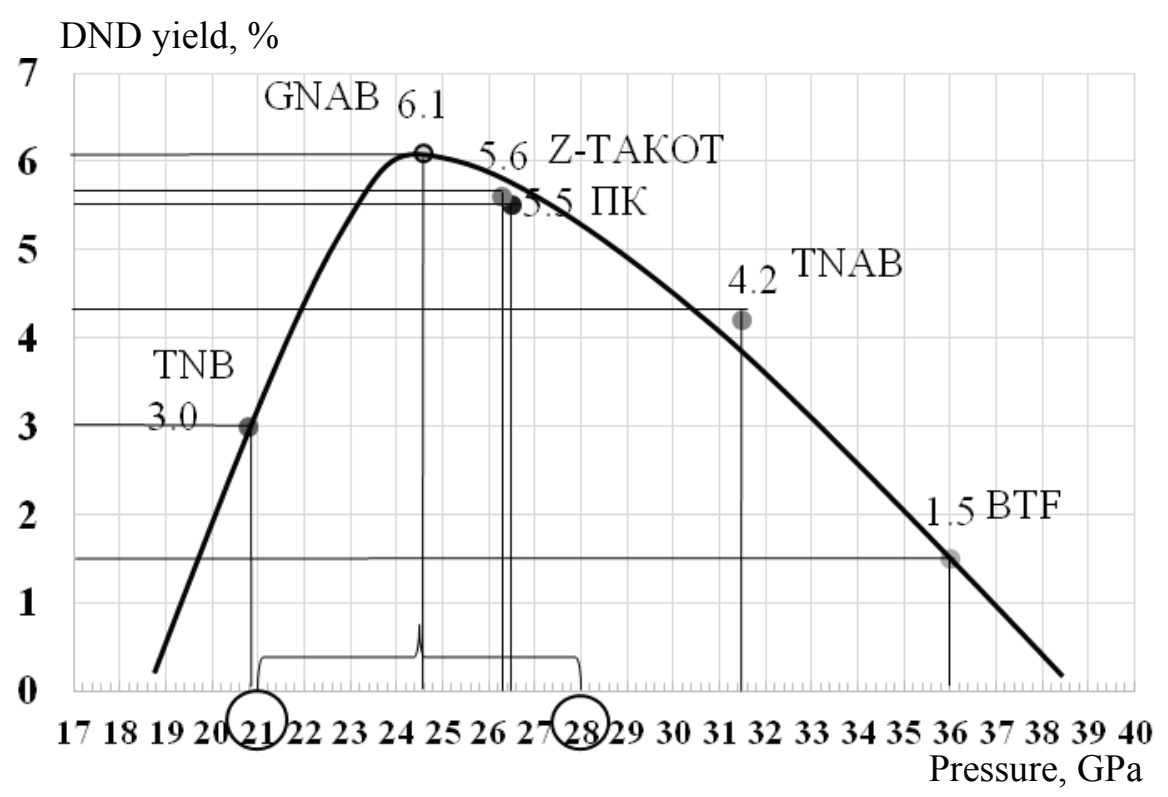

Fig. 2. Dependence of the DND output on the pressure in the Ch-J. plane during EM charge detonation [21]

Since the most known value is the detonation velocity EM (D) (depending on the charge density), it is advisable to use it to determine the approximate specific power (SP) of an EM, and with its help - the DND output.

If for EM the pressure in the Ch-J plane is known, then based on Fig. 2, you can also determine the expected DND output. To check the forecast results, it is necessary to synthesize DND at a EM charge density $\sim 1.6-1.7 \mathrm{~g} \cdot \mathrm{cm}^{-3}$ in water armor.
Thus, the obtained predictive data on the DND yield can be used for a rough prospects assessment of using EM charges.

\subsubsection{Process of DND synthesis from individual, binary and triple EM charges}

The use of the water (or water-urotropine) shell of the charge made it possible to increase the time of maintaining the $P, T$-conditions in the zone of chemical reactions, and effectively reduce the 
temperature in post-detonation processes, while preserving the formed DNDs.

In [2], the authors tested the conditions for obtaining DND from tetryl according to [30] (without a shell). However, the yield of nanodiamonds turned out to be negligible (0.37 wt.\%) and unsuitable for industrial production. Only the use of an aqueous or water-urotropine shell increased the yield of nanodiamonds by $\sim 20$ times - up to $6.3-7.05$ wt.\% with a minimum amount of incombustible impurities in DND - 0.36-0.94 wt.\%. This method, taking into account the large reserves of tetrile, makes it possible to recommend the developed method for obtaining DND in industrial production. The oxygen balance of tetryl $-47.4 \%$ is within the recommended range of $-35 \div-55 \%$ [24], and the charge density, at a sufficiently safe pressing pressure of $1,200-1,400 \mathrm{kgf} \cdot \mathrm{cm}^{-2}$, is the recommended value of $\sim 1.64 \mathrm{~g} \cdot \mathrm{cm}^{-3}$ [24]. The oxygen balance, which is in the range of $-45 \div-50 \%$, and the EM charge density in the range of $1.62 \div 1.65 \mathrm{~g} \cdot \mathrm{cm}^{-3}$ make it possible to provide an economically acceptable DND yield in an amount of $5 \mathrm{wt} . \%$ for individual EM.

Thus, a new industrial method for obtaining DND from individual EM tetryl with a high yield (6-7 wt.\%) and a high content of DND in the diamond charge (51-63 wt.\%) Has been developed, which greatly simplifies the chemical purification of DND.

Double compositions with tetryl, with its content of more than $50 \%$ with TNT, RDX and picric acid, give DND yield in the range of 5.2-7.34\%. The charge yield is from 10.0 to $16.2 \mathrm{wt} \% \%$ [2].

Figure 3 shows the dependence of the nanodiamond yield on the tetryl content in binary mixtures, from which it follows that as the tetryl content increases, the DND yield also increases to $7.34 \%$. The most effective additive to tetryl is TNT, it is slightly inferior to RDX, the lowest yield of DND was obtained when picric acid (PA) was used as an additive.

The use of tetrile, rather than binary compounds, is more expedient, since it excludes:

- the use of RDX, which is very scarce, expensive and dangerous in circulation;

- dangerous operation of mixing tetrile with TNT, RDX or PA;

- the operation of crushing TNT or its recrystallization.

When selling products in the form of DC, the greatest demand will be for the product with the maximum amount of DND in the DC. It was shown in [2] that for this purpose it is advisable to recommend a charge composition containing TNT-RDX 60/40, TNT-RDX 50/50, or pure tetryl.

Thus, it has been shown that tetryl is the only commercially available individual EM suitable for obtaining DND with a high (up to $~ 7.5 \%$ ) yield; binary mixtures with tetryl can give a DND yield of up to $7.34 \%$ (in water armor). To obtain DC with the highest (up to 63\%) DND content, the use of individual tetryl is optimal.

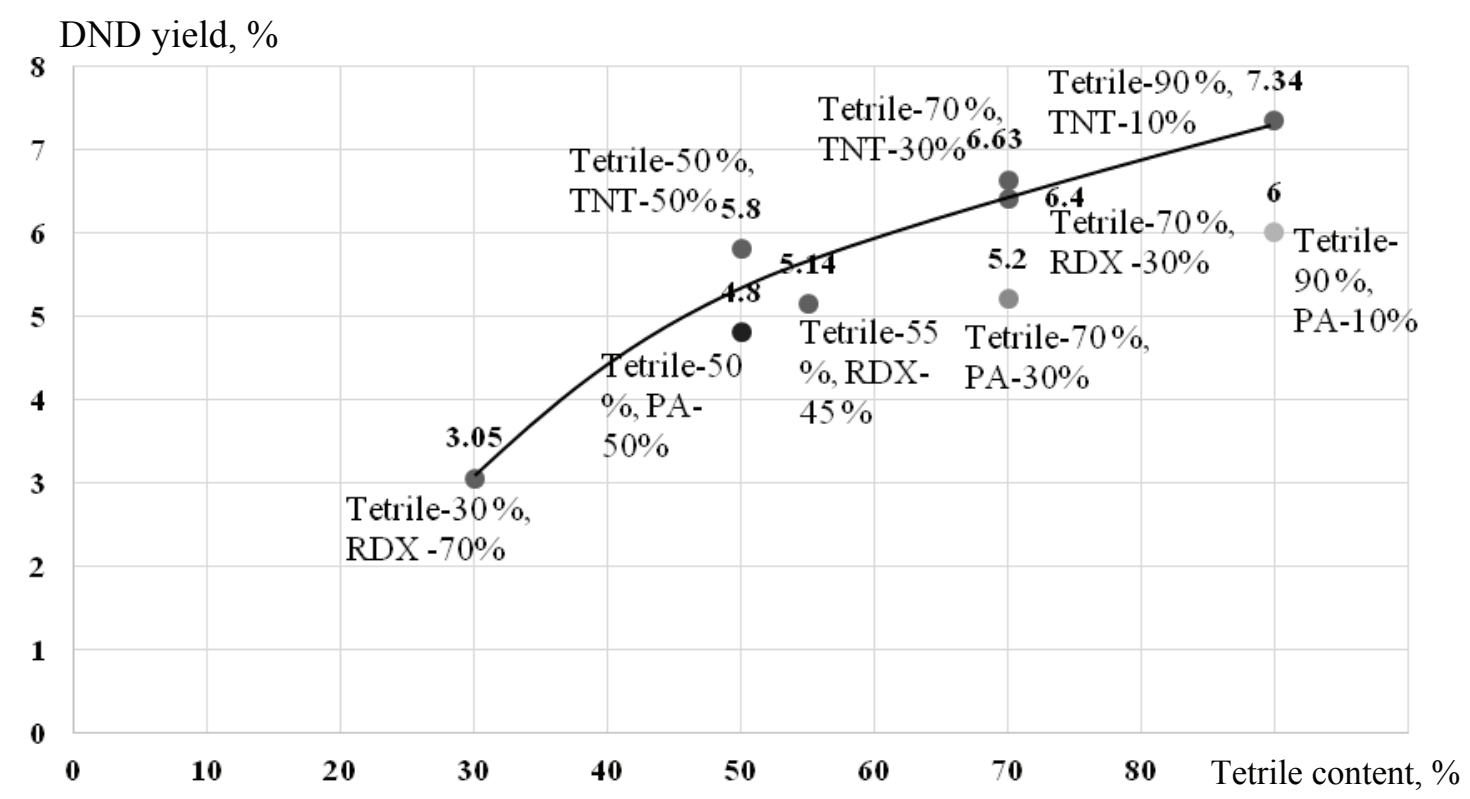

Fig. 3. Dependence of the nanodiamond yield on the tetryl content in binary mixtures [2] 
To obtain DND, it is possible to use not only conventional double charges, but also more complex ternary compositions, including those based on tetryl [31]. Such charges make it possible to more accurately control the $\mathrm{CB}$, density, and, ultimately, the DND yield. In addition, the replacement of RDX with conversion tetryl is economically feasible.

It has been shown that the maximum DC yield is also achieved when using 50 wt.\% tetrile with TNT-RDX 70/30 (50 \%) and TNT-RDX 50/50 (50 \%). In these examples, the maximum DND yield is achieved -7.94 and $8.18 \%$, respectively.

It was established in [32] that DNDs obtained from tetryl have a size of $\sim 5 \mathrm{~nm}$. NMR and EPR data show that the size and structure of tetryl DNDs is similar to nanodiamonds from a classic tetrylhexogen alloy or a ternary mixture (tetryl + TNT + + hexogen). The $\mathrm{C}^{13}$ NMR spectra and the behavior of the spin-lattice and spin-spin relaxation rates correlate with those for TNT-hexogen DNDs. The data obtained indicate, most likely, a single mechanism for the formation of nanodiamonds in ZCR, independent of the EM used or their mixtures.

\section{Diamond charge and its cleaning}

\subsection{General properties of $D C$}

DC is a physicochemical system containing diamond-type carbon structures and various graphitelike structures. Most of the non-diamond form of carbon is located on the surface of the diamond core, the fragments of which are connected not only physically, but also by chemical bonds. The isolation of nanodiamonds with reproducible characteristics is impossible without chemical treatment, which provides an energetic effect sufficient to break strong carbon-carbon bonds.

In the technology of obtaining nanodiamonds, chemical purification is the most expensive and difficult stage. Purification technologies determine the operational characteristics of nanodiamonds, and the degree of complexity of their implementation determines the level of DND cost and its availability for various applications. When passing from DC to nanodiamonds, the textural characteristics of the substance change not monotonically, but in a jumplike manner, which distinguishes the charge from other carbon materials [12].

Chemical cleaning of the charge in the liquid phase, combines the processes of oxidation and acid dissolution of metals, and is the most effective. Many methods have been proposed for its implementation. In [33], oxidative treatment is proposed, when the charge is in the form of a suspension with a solid phase concentration of no more than $5 \%$, with an aqueous solution of ammonium nitrate in weak nitric acid with $\mathrm{pH}<1$. Ammonium nitrate is taken in a significant excess with respect to DC - 10-15 wt.\% $\mathrm{NH}_{4} \mathrm{NO}_{3}$ per $1 \mathrm{wt}$. part of the charge. The process is carried out at a temperature of $210-225^{\circ} \mathrm{C}$ until the completion of gas evolution, which indicates the completion of the oxidation process and the decay of ammonium nitrate. The decomposition of $\mathrm{NH}_{4} \mathrm{NO}_{3}$ under oxidation conditions proceeds to nitrogen, and the released oxygen is consumed for the oxidation of nondiamond carbon. The presence of $\mathrm{HNO}_{3}$ in the reaction mixture ensures the dissolution of metal impurities in the form of soluble metal nitrates.

The advantage of the method is the absence of toxic nitrogen oxides in the gaseous reaction products, which makes it possible to completely abandon expensive systems for the absorption and regeneration of nitric acid. In addition, the low content of nitric acid in the spent reaction mass makes it possible to completely eliminate acid turnover.

\subsection{Composites based on partially oxidized charge of detonation synthesis nanodiamonds}

Controlled stopping of the DC oxidation process at various stages makes it possible to obtain a product of a given composition, structure, and the required characteristics [34]. From the experimental curves reflecting the kinetics of oxidation, it follows that, depending on the temperature and other initial conditions, there is a transition from a slowly proceeding oxidation reaction of non-diamond carbon to a self-accelerating oxidation process with the completion of the reaction. Carrying out the oxidation process under pressure makes it possible to expand the oxidation temperature range, limited by the boiling of the liquid reaction mass, and significantly reduce the requirements for the permissible concentration of nitric acid and its excess.

Oxidation of non-diamond carbon in DC with nitric acid can proceed to different degrees of reduction and a different set of reaction products (NO, $\mathrm{NO}_{2}, \mathrm{~N}_{2} \mathrm{O}, \mathrm{N}_{2}$ ). In DC, the following carbon structures can be distinguished by reactivity: 1) Amorphous carbon (residues of short carbon fragments and aromatic rings); 2) Disordered graphite-graphene fragments; 3) Dense "stacks of graphite-graphene structures" with limited access of the oxidizing agent due to steric hindrances. Using 
the example of DC oxidation with 5-10\% nitric acid, it was shown that by varying the temperature, the reaction can be inhibited at any desired conversion stage within the range of 0-90\%. Figure 4 shows a diagram of the preparation of graphite-diamond nanocompositions.

Graphite-diamond nanocomposition $\mathbf{1}$ is a graphite-diamond composition after removal of amorphous carbon and disordered aromatic rings of graphite structures. Contains the maximum amount of carboxyl groups 4-5 wt.\%. The content of diamonds is from 55 to $60 \mathrm{wt} . \%$.

Graphite-diamond nanocomposition $\mathbf{2}$ is a graphite-diamond composition obtained by oxidation of a graphite-graphene shell, with fixation of oxygencontaining groups on carbon $s p^{2}$ of aromatic rings, the content of carboxyl groups is 2-3 wt.\%. The content of the diamond phase is from 60 to 85 wt.\%.

Graphite-diamond nanocomposition $\mathbf{3}$ is a graphite-diamond composition obtained by oxidation of residual aromatic structures of carbon $s p^{2}$ and carbon of $s p^{3}$-transition structures. The content of carboxyl groups varies from 2 to 0.5 wt.\%. The content of diamonds is $85-95$ wt.\%.

Thus, 1) the oxidation of the diamond-containing charge of detonation synthesis with aqueous solutions of nitric acid under pressure in the temperature range of $120-230^{\circ} \mathrm{C}$ at various ratios of the reagents was investigated. The range of values of the main parameters has been identified, which allows the selective oxidation of the graphite shell to a given ratio of the diamond and graphite phases; 2) a probable scheme of the reaction as a radical chain process is proposed, which includes the mechanisms of chain formation and the sources of its development during the oxidative process with the participation of radical-like nitrogen dioxide.

\section{DND properties}

\subsection{DND structure}

Primary DND particles have a complex structure $[8,27,35-37]$. According to the assumption of the authors of [8], they are a giant molecule, in which the carbon part is represented by a diamond core, surrounded by a non-diamond carbon shell, with which a layer of surface functional groups is connected (Fig. 5). Purified DND is a gray powder containing aggregates of primary particles of various sizes and different strengths $[1,3,5,7]$. The content of impurities depends on the conditions of DND synthesis, methods of its purification and subsequent modification $[4,5,36-42]$. On average DND contains oxygen (up to $7 \%$ ), hydrogen (0.4-1.8\%), nitrogen $(\sim 2.5 \%)$ and an incombustible residue $(0.3-7.0 \%)$, consisting of oxides and salts $\mathrm{Fe}, \mathrm{Cr}, \mathrm{Cu}, \mathrm{Ca}, \mathrm{Si}, \mathrm{Zn}$, etc. Oxygen, nitrogen and hydrogen are partially included in the composition of compounds sorbed on DND (carbon monoxide and dioxide, nitrogen, water, etc.), which can be located on an accessible surface or be Aggregates of nanoparticles are "walled up" in closed pores. But the other part of these atoms is part of the surface functional groups. They are an integral part of the DND supramolecule. Functional groups can be destroyed, exchanged for others, but they are always present on the DND surface, as well as on the surface of macrocrystals and grains of diamond powders of other genetic types.

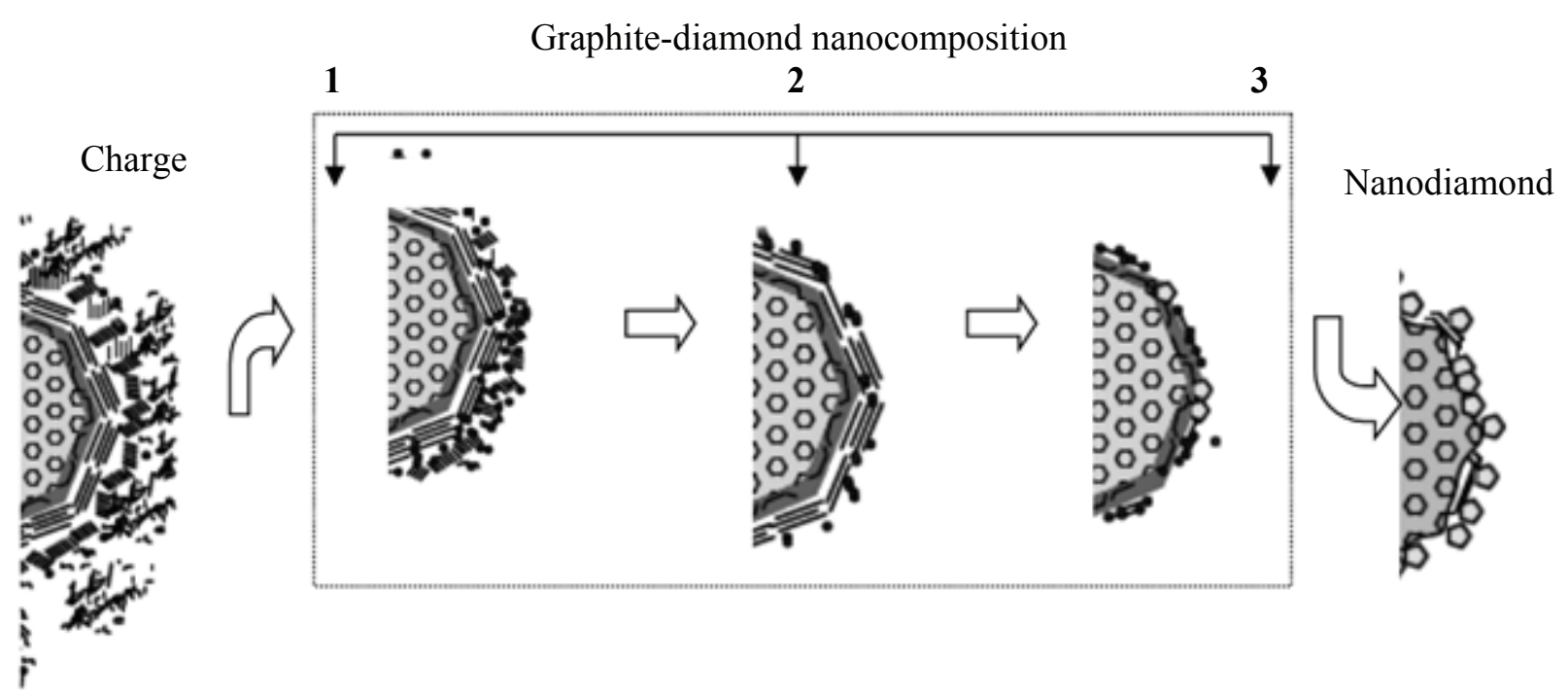

Fig 4. Scheme of obtaining graphite-diamond nanocompositions of various types from DC [34] 


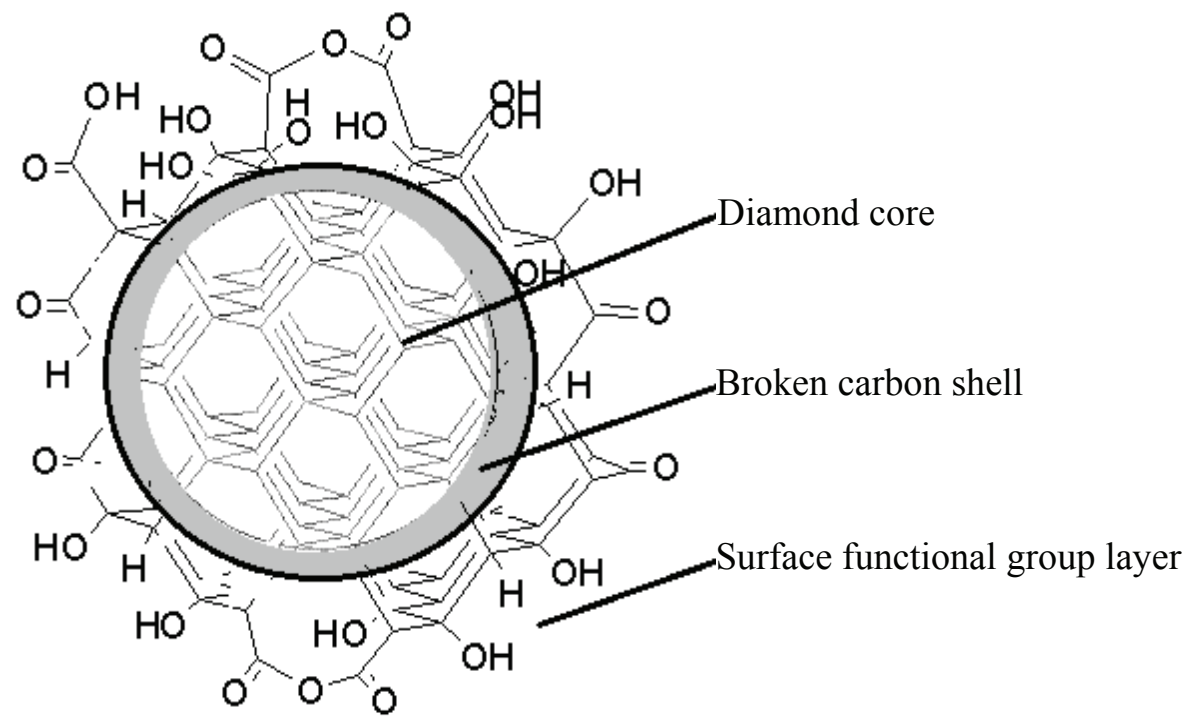

Fig. 5. Possible model of the structure of the primary particle of DND [5, 8]

When studying the diffraction of electrons on DND samples (trade mark UDA-SF FSUE SKTB Technolog, St. Petersburg) and subjected to various chemical treatments, a diffraction pattern typical for diamond is observed [5, 40]. Decomposition of the (111) reflection in a Fourier series made it possible to obtain the crystal potential distribution curve and to confirm that the primary diamond particle has an average size of $5 \mathrm{~nm}$, the diameter of the diamond core being $\sim 3 \mathrm{~nm}$, and the thickness of the surface carbon layer $\sim 1 \mathrm{~nm}$. The latter has a broken diamond structure, since there is no sharp boundary for the change in the crystal potential.

The symbate dependence of the yield of carbon dioxide and nitrogen during DND oxidation to complete oxidation of the sample indicates that nitrogen is uniformly distributed throughout the volume of the DND particle.

It was shown in [43] that the factor limiting the growth $(\leq 8 \mathrm{~nm})$ of the diamond core in DNDs is the violation of long-range order in DNDs, the accumulation of crystal structure defects as the carbon nanoparticle grows in post-detonation processes. Comparison of the distribution of carbon atoms in DND and in defect-free diamond, which differ in lattice parameters, shows that in nanosized diamond there is a change in the coordination number (CN) in the outer coordination spheres (CS). The CS has the absence of atoms (lattice defects), which changes the structure and morphology of the DND surface. Defective structures are more reactive and oxidize more easily during chemical processing.

On the surface of DND particles there is a cover consisting of various functional groups, mainly oxygen-containing, including carboxyl, ester, ether, lactone, etc., which determines the non-selectivity of the reactions of its modification [5]. The nature of these groups and their ratio are determined by the peculiarities of the technologies for obtaining, isolating and purifying DND [1, 3, 5, 7, 8, 44, 45]. In addition to these functional groups, depending on the processing conditions, halogen- and nitrogencontaining (amine, amide, cyano and nitro groups), sulfone and other groups can be associated with the surface of nanodiamonds [5, 46-51].

$\mathrm{O}-\mathrm{H}$ stretching vibration bands $(3,500-$ $3,200 \mathrm{~cm}^{-1}$ ) are present in all spectra, the shape depends on the type of DND, the maxima of asymmetric and symmetric bands at 3,410 and $3,230 \mathrm{~cm}^{-1}$ correspond to particles with strong hydrogen bonds and, in some cases, to the $3,290 \mathrm{~cm}^{-1}$, which is probably an overtone band of liquid adsorbed water [45]. All types of DND differ in the position of the main maximum and in the carbonyl band width of about $1,750 \mathrm{~cm}^{-1}$. For most varieties, it is located at $1,740 \mathrm{~cm}^{-1}$, for DND-TAN and DND-STP (manufactured by FGUP SKTB Technolog, St. Petersburg, Russia), it is located at $1,786 \mathrm{~cm}^{-1}$. The reproducibility of this band is the highest among other bands in the spectrum, and it is usually the same for different brands of the same manufacturer, for example, for DND-TAN and DNDSTP. In terms of the characteristics of the DND brand, groups of nanodiamonds can be distinguished by the amount of bound water $\left(1,630 \mathrm{~cm}^{-1}\right)$ and the intensity of the $\mathrm{OH}$ continuum $3,600-3,000 \mathrm{~cm}^{-1}$ and carboxyl groups $\mathrm{C}=\mathrm{O}$ and $\mathrm{C}-\mathrm{O}-\mathrm{H}$ bands at $1,760-1,740$ and $1,440-1,340 \mathrm{~cm}^{-1}$, respectively. 


\subsection{Electron Paramagnetic Resonance of detonation nanodiamonds}

The phenomenon of magnetic resonance is the resonant absorption of electromagnetic radiation by quantum objects with non-zero spin values, subjected to an external static magnetic field. These objects may be unpaired electron spins (the cases of Electron Spin/Paramagnetic Resonance ESR/EPR and its derivatives Electron Nuclear Double Resonance ENDOR, Optically Detected Magnetic Resonance ODMR etc.) or non-zero nuclear spins (the cases of Nuclear Magnetic Resonance - NMR and closely related Magnetic Resonance Imaging - MRI). Both a deep theoretical background and application of various magnetic resonance techniques to studies of a large variety of physical objects may be found in Refs. [52-54]. These non-destructive techniques provide researchers and technologists the potential to uniquely identify the electron-nuclear structure of various substances containing magnetic species, from gases to complex biological molecules. They are capable of providing important information on the structure and dynamics of a system, including the chemical and physical processes occurring there.

Plenty of defects and impurities in crystalline diamond samples (including the most intriguing optically active triplet centers like $\mathrm{NV}^{-}$) carry nonzero electron spins which makes EPR and related techniques the most adequate ones for providing useful information on the anisotropy of electronic $g$ tensor; zero field couplings in species with $S>1 / 2$; hyperfine interaction with principle nuclei of surrounding atoms, etc. [52]. Traditionally, these phenomena are interpreted within the framework of the spin-Hamiltonian ( $\mathrm{SH}$ ) concept, where $\mathrm{SH}$ is an energy operator describing all existing interactions (electric, magnetic, exchange) of the electron and nuclei spins with their surrounding and external fields applied [53, 54]. Useful data obtained from EPR spectra are presented as corresponding SH parameters ( $g$-values, hyperfine splitting $A$, zero-field splittings $D, E$ etc.). Well-developed theoretical tools in combination with state-of-the-art experimental techniques allow one to obtain tiny details of a defect's nature, surroundings and interactions. However, the EPR study of DND samples has its specificity dictated by the form of the diamond sample. In many cases, conventional EPR deals with bulky samples. In contrast to well-ordered single crystal diamonds and crystalline diamond films, bulky DND samples appear as non-oriented powders. Dynamic synthesis techniques (detonation, shock wave, laser ablation) provide diamonds in the form of nanometer-sized powders; a typical sample is an ensemble of small particles characterized by a distribution of individual sizes and properties of these particles. Thus, EPR spectra of DND samples are spatially averaged, which causes certain decrease in spectral resolution, reduction in sensitivity (due to additional line broadening) and complications in interpretation of the EPR data. Moreover, the specificity of DND synthesis conditions and high surface-to-volume ratio (characteristic feature of all nanoparticles) induce unusual densities of some defects thus confusing the hierarchy of interactions between magnetic centers. The latter brings new complexity in deciphering of EPR spectra.

Real DND samples demonstrate a large variety of magnetic properties which descend mainly from the origin of the samples as well as any subsequent treatments performed on them. For instance, each DND particle inherits, first of all, some magnetic features of its ancestors. Further, the detonation synthesis itself creates new carbon inherited defects within surface layers of nanoparticles and may be considered as a source of synthesis originated magnetic impurities. First, there should be clear discrimination between two types of defects: those that are either inherent or induced in the diamond core or on/within the surface/interface layer of the diamond nanoparticle as a result of the synthesis (e.g. atoms from initial explosives etc.); and those that are not directly induced on or within the diamond, but are instead unrelated magnetically active impurities which may stem from various post-processing techniques (e.g. impurity contamination the detonation synthesis chamber). In both research and practical applications of DND, the most of uncontrolled impurities are undesirable species that may (and have to) be removed by the proper choice of a purification technique [55]. In this respect just EPR is a powerful analytic tool for assessing the content of initial magnetic impurities and the efficacy of purification procedures. Non-impurity magnetism in DND originates from three main sources: (i) intrinsic paramagnetic defects inherited from source materials, where these defects were created in the process of diamond formation or synthesis (e.g. metallic impurities from catalysts, nitrogen); (ii) defects induced by synthesis (e.g. dangling bonds along cleavage planes); and (iii) intentionally induced defects introduced to modify the properties of the initial diamond material (e.g. $\mathrm{NV}^{-}$centers or other irradiation induced defects). The latter type of defect may be sub-classified into: defects attached to the diamond surface and subsurface interface layers by modification of the surface chemistry (particularly in smaller particles with high specific surface area); and 
defects induced by ionizing irradiation/ion implantation of raw diamond materials or resulting small particles.

Detonation technique of diamond synthesis directly provides diamond particles of nanometric sizes. In the most cases size distribution in DND samples is quite narrow with the average particle sizes below of $\sim 4-6 \mathrm{~nm}$. In facts, real DND samples rarely consist of well separated single nanoparticles but are rather quite large (hundreds of nanometers or even micron-sized) polycrystalline aggregates of single ND particles. Various techniques are used for disaggregation of these entities into solitary ND crystallites, but all of them are much "softer" than usual nanonization processes applied to bulk crystalline diamonds. It has been demonstrated that disaggregation did not create additional mechanically induced paramagnetic defects $[56,57]$. Thus, all paramagnetic defects in initial (non-modified) DND are intrinsic defects, emerged in DND particles at their generation.

Already early EPR studies of detonation DND revealed well pronounced paramagnetism. DND samples synthesized by different explosion techniques and obtained from different manufacturers exhibited similar EPR characteristics, more specifically: absence of characteristichyperfine EPR patterns due to substitutional paramagnetic nitrogen in diamond lattice (so called P1 or N0 centers) and presence of a strong singlet Lorentzian-like signal with $g=2.003$ and line width $\Delta H_{\mathrm{pp}} \sim 0.7-1.0 \mathrm{mT}$ attributed to paramagnetic $S=1 / 2$ defects in the diamond structure (dangling bonds etc.). The results of the measurements done on various detonation DND powders are summarized in Refs. [56, 58] and references therein. Precise measurements of the $g$-factor for the most intensive signal provide $g=2.00282 \pm 0.00003$ within the temperature range of 4.2-300 K. The observed shift of this $g$-factor from the free electron value $\left(g_{\mathrm{e}}=2.0023\right)$ may be interpreted in terms of the model of unpaired spinslocalized at a mesoscopic object (to which DND particles belong as well). This interpretation allows estimating the size of the DND particle as 20-60 $\AA$, which correlates well with the DND dimensions derived from XRD and HRTEM. Careful SQUID and EPR study of well purified detonation DND (sample ND2) revealed the density of $S=1 / 2$ spins $6.3 \times 10^{19} \mathrm{spin} / \mathrm{g}$ or $1255 \mathrm{ppm}$, which corresponds to 13-15 $S=1 / 2$ defects per each DND particle [59]. The defects' densitiesin diverse DND samples of different originsvary around the density in ND2 with deviations not exceeding $30 \%$. Thus, DND fabricated from non-conventional explosives (like
Tetryl) show the same EPR characteristics as the aforementioned ND2 sample (i.e. $g=2.0028 \pm$ $\pm 0.0002, \Delta H_{\mathrm{pp}}=0.72 \mathrm{mT}$ and $0.80 \mathrm{mT}$ for the DNT1 and DNT7 samples, correspondingly), but enchanced defects' densities 1481 ppm (DNT1) and 1,793 ppm (DNT7) [32] - see Fig. 6, a. Analysis of the EPR spectra revealed that the singlet Lorentzian-like line observed consists of two main Lorentzian components: broad and narrow ones - see Fig. 6, $b$ and Ref. [60]. It was suggested that broad and narrow signals are due to two types of $S=1 / 2$ defects somehow differing by their both origin and location.

Modification of DND by grafting the DND surface with transition metal ions (for instance divalent copper $[60,62]$ and trivalent gadolinium [63], being itself promising and useful method for design of DND with controlled characteristics [64], also appeared to be helpful in the attribution of broad and narrow lines [62]. Direct observation of $\mathrm{Cu}^{2+}$ and $\mathrm{Gd}^{3+}$ EPR signals allowed acceptable estimation of the number of transition metal ions attached to the DND surface. Thus, $\mathrm{Cu}^{2+}$ ionswere used as paramagnetic probes which interact (by dipole-dipole and exchange channels) with the intrinsic $S=1 / 2$ defects. Varying modification conditions one can control the strength of the said interactions which, in turn, allowed estimating distances between paramagnetic probes and different types of intrinsic defects. It was found that surface located $\mathrm{Cu}^{2+}$ ions cause broadening of the both types of EPR lines originated form $S=1 / 2$ defects, but such a broadening is more pronounced for the broad lines and less - for the narrow lines [60, 62]. Such a behavior indicates that defects responsible for the broad lines are located closer to the DND surface than those ones responsible for the narrow line. The estimated depths of occurrence for two types of intrinsic $S=1 / 2$ defects were found to be $\sim 0.8 \mathrm{~nm}$ and $\sim 1.5 \mathrm{~nm}$ from the DND surface for the shallow and deeper defects, respectively. It may be supposed that the intrinsic $S=1 / 2$ defects in DND belong to at least two main groups differing first of all by their location inside the DND particle. The defects located at average distances of less than $1 \mathrm{~nm}$ from the surface are responsible for the broad Lorentzian component of the main EPR signal. Defects of another group, associated with the narrow Lorentzian component, are located deeper from the surface at average distances $\sim 1.5 \mathrm{~nm}$. May defects of the first group be attributed to surface defects or are they "hidden" within the subsurface interface layers? EPR provides univocal answer to this question [58] reports on the experiments with evacuated DND samples. 

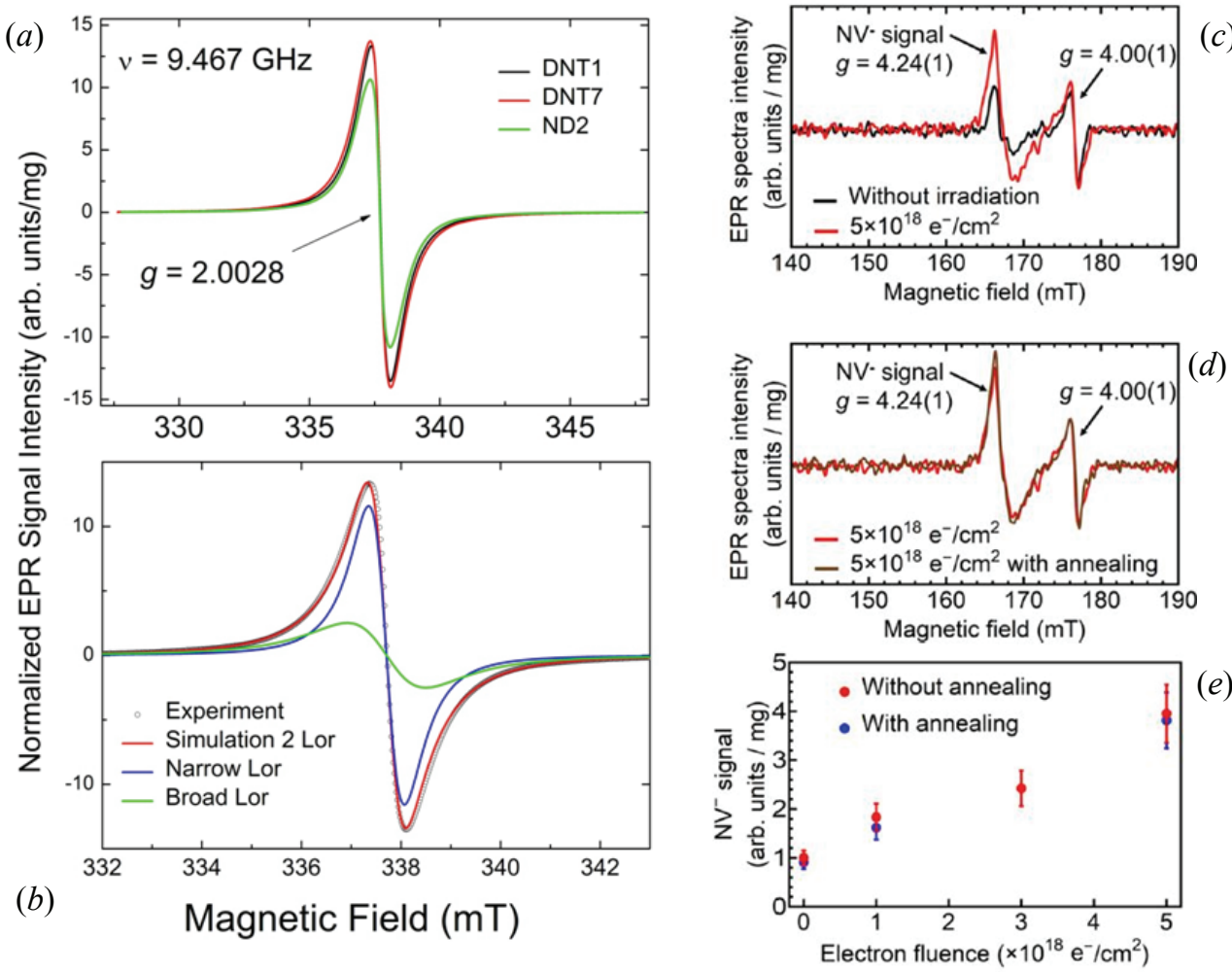

Fig. 6. EPR study of DND samples:

$a$-X-band EPR spectra of DND samples DNT1 (black traces), DNT7 (red trace) and ND2 (green trace) recorded at room temperature and $v=9.466 \mathrm{GHz}[32] ; b-$ deconvolution of the experimental EPR spectrum of DNT1(black circles) into two Lorentzian lines with the same $g$-factor 2.0028: best least square fitting with 2 lines (red trace), narrow component with $\Delta H_{\mathrm{pp}}=0.72 \mathrm{mT}$ (blue trace), broad component with $\Delta H_{\mathrm{pp}}=1.58 \mathrm{mT}$ (blue trace); $c-$ half-filed EPR spectra of DND before (black trace) and after electron irradiation with fluence $5 \times 10^{18} \mathrm{e}^{-} \cdot \mathrm{cm}^{-2}$ (red trace) recorded at room temperature and $v=9.87 \mathrm{GHz} ; d$ - half-field EPR spectra of electron irradiated DND samples before (black trace) and after annealing at $800{ }^{\circ} \mathrm{C}$ for $2 \mathrm{~h}$ under vacuum (red trace); $e$ - dependence of the $\mathrm{NV}^{-}$content in irradiated DND sample on the e-beam fluence [61]

Air evacuation increases doubly integrated intensity of the main EPR signal for about $10 \%$ with no changes in its line shape, widths and positions of the signal. When the sample was open to air again, the intensity of the signal returned to its initial value. Such an effect may be understood it terms of exchange broadening of EPR lines of the defect's spins due to encounters with molecules of triplet oxygen $\left(\mathrm{O}_{2}\right)$, which is well known magnetic agent contained in air. Thus, there are some defects in the first group which are located on the surface of the DND particle or close enough to the surface for interacting with molecular oxygen. From the aforementioned $10 \%$ reduction of the intensity it may be concluded that a single $S=1 / 2$ defect may be located on the surface of a DND particle. Other defects in this group are well isolated from encounters with oxygen molecules because of their location inside subsurface interface layers. Following direct analogy with carbon-inherited defects, induced in diamond particles by nanonization, this group of defects may be attributed to dangling bonds located within the distorted diamond structure of interface layers. Thesecond group of inherent defects in DND, which is located at least twice deeper inside the ND particle, is responsible for the narrow Lorentzian component of the EPR signal. The same narrow line is observed in EPR spectra of fine ND fractions obtained by nanonization of micron-sized type $\mathrm{Ib}$ HPHT diamonds [65]. There it was supposed that such a line originates from P1 centers strongly interacting with large amount of mechanically induced dangling bonds. It is logical applying the same model to DND. Indeed, typical P1 hyperfine split patterns have never been reliably observed in EPR spectra of DND. On the other hand, it is well known on the presence of high abundance of nitrogen in DND. Thus, the absence of characteristic P1 signals sounds quite puzzling. However, the hypothesis proposed in the Ref. [65] may 
successfully solve the puzzle: namely, narrow Lorentzian component in EPR spectra of DND is due to nitrogen substitution defects (P1) which are located into the crystalline core of aDND particle and strongly interact with uncoupled electron spins of multiple dangling bonds located into interface layers. In such configuration (and there are no other configuration in small DND particles!) the conventional hyperfine split pattern cannot be observed at all [66].

$\mathrm{X}$-band EPR study at $4 \leq T \leq 300 \mathrm{~K}$ of well purified DND [58] revealed the presence within the half-field region two additional (to the main intense $S=1 / 2$ signals) weak and narrow signals with $g_{1}=4.26(1), \Delta H_{\mathrm{pp}}=2.9(1) \mathrm{mT}$ and $g_{2}=4.00(1)$, $\Delta H_{\mathrm{pp}}=1.4(1) \mathrm{mT}$ at $\left.T=4 \mathrm{~K}\right)$, separated by the distance of $10.4 \mathrm{mT}$. Integral intensity of these signals was found to be several orders of magnitude lower than the same for the main signal. It was supposed that these doublet signals appear due to "forbidden" fine transitions between Zeeman states of some triplet centers. Further the same doublet signals were found in X- and Q-band $(9.4$ and $34 \mathrm{GHz}$, correspondingly) EPR spectra of a large variety of intact, purified and modified nanodiamonds obtained from various manufacturers and synthesized by different dynamic synthesis techniques (detonation, laser, "Du Pont") [67]. Careful analysis of EPR spectra collected from multiple samples showed that these signals, in spite of having frequency dependent $g$-factors and splitting as well as sample dependent line widths and relative intensities ratios, always present in EPR spectra of DND and may be attributed to two different types of triplet paramagnetic centers: the X-band $g_{1}=4.26$ signal is characteristic for $\mathrm{NV}^{-}$ defects whereas the X-band $g_{2}=4.00$ signal is characteristic for exchange coupled $S=1 / 2$ defects (multivacancies) - Figs. 6, $c, d$. Here it is worth mentioning that the 'allowed' lines, always accompanying 'forbidden' lines in EPR spectra of $\mathrm{NV}^{-}$triplets recorded on bulky fluorescent diamonds and coarse fluorescent nanodiamond fractions, have never been observed in DND. Assumed nature of this phenomenon observed in fine fluorescent nanodiamond fractions is discussed in [67].

These two universal types of triplet centers are minor rare defects in all DND independently of the type of dynamic synthesis and precursors. The ultimate confirmation of the correctness of the above attribution was done by comparison of half-field EPR spectra of DND with similar spectra of fluorescent nanodiamonds obtained by nanonization of electron irradiated micron-sized HPHT diamonds [68].
Thus, it may be concluded that each DND sample contains certain amount of inherent (i.e. created by the synthesis itself, not induced by intentional high energy irradiation and/or nanonization) triplet $\mathrm{NV}^{-}$and multivacancy defects. The actual content of each of these defects depends on a synthesis technique, starting materials and conditions as well as post-processing. The highest abundance of inherent $\mathrm{NV}^{-}$defects, well compared with the same abundance in fine fluorescent (irradiated/annealed) nanodiamonds, was found in DND disregarding of their type of the conventional DND precursors - nitrogen-based explosives. It has been recently demonstrated [61] that the ability of DND particles for generating $\mathrm{NV}^{-}$centers inside themselves is not limited to just those triplet centers born in the process of detonation synthesis: irradiation of conventional DND by high energy electron beam results in significant enhancement of the lower field line in the half-field EPR spectrum of the irradiated sample (see Fig. 6, c). This enhancement undoubtedly indicates enrichment of the DND particle by $\mathrm{NV}^{-}$centers. Interesting, that, in contrast to irradiated HPHT nano- and microndiamonds, annealing of the irradiated DND sample at $800{ }^{\circ} \mathrm{C}$ for $2 \mathrm{~h}$ under vacuum does not practically change the $\mathrm{NV}^{-}$content (see Fig. $6, c$ ). This puzzling feature is still within the focus of ongoing investigations. On the other hand, the fluence dependence (Fig. 6,e) is found to be in line with the same dependence found for HPHT crystallites [69].

\section{Application of detonation nanodiamonds}

\subsection{Electrochemical metal-diamond coatings}

\subsubsection{The electrochemical deposition process of gold-diamond coatings}

Composite coatings are divided into five groups - wear-resistant, antifriction, corrosionresistant, frictional and coatings with surface strength, hardness and heat resistance.

The use of detonation diamonds (DND) in electroplated coatings is an illustration of their successful application. Composite electrochemical coatings (ECC) with DND have high hardness, strength and resistance to wear, corrosion and weathering. These properties are due to changes in the ECC structure caused by the inclusion of nanoparticles in the range from 0.1 to $1.0 \%$.

The doped (alloyed) nanodiamonds used in this work with phosphorus or boron were obtained by the explosion of a mixture of TNT with RDX in an aqueous shell; moreover, up to $5 \mathrm{wt} . \%$ was added to 
the charge during molding, with thorough mixing. phosphorus or boron compounds - triphenyl phosphate (DND-32B), sodium tetraphenylborate (DND-27B), potassium tetraphenylborate (DND36B) [70]. In addition, DND-STP were used - these are standard (classical) detonation nanodiamonds; DND-TAN is DND-STP, but subjected to treatment with $\mathrm{NH}_{4} \mathrm{OH}$ at $\sim 225^{\circ} \mathrm{C}$ and pressure up to $50 \mathrm{~atm}$; DND (Japan) - DND-STP, from which prof. E. Osawa (Japan) nanoparticles less than $8 \mathrm{~nm}$ in size [71]; DND-FTI-1 - DND-STP, from which nanodiamond particles $\sim 5 \mathrm{~nm}$ were isolated in the laboratory of prof. A.Ya. Vul (St. Petersburg, Russia) to a size of $\sim 5 \mathrm{~nm}[72]$.

Gold coating of phosphate electrolyte when using DND-TAN and DND-FTI-2 (doped with boron) has a microhardness of $177-198 \mathrm{kgf} \cdot \mathrm{cm}^{-2}$ at an application temperature of $20-25^{\circ} \mathrm{C}$, which is close to the microhardness of films from citric acid electrolyte. The greatest increase in microhardness at density current of $3 \mathrm{~mA} \cdot \mathrm{cm}^{-2}$ is achieved with explosive injection into DND electrolyte (Japan) up to $221 \mathrm{kgf} \cdot \mathrm{mm}^{-2}$. DND-FTI-1 $\left(2 \mathrm{~mA} \cdot \mathrm{cm}^{-2}\right)$ has similar values, an increase in microhardness by $25-30 \mathrm{kgf} \cdot \mathrm{mm}^{-2}$ (up to $20 \%$ ).

The tests of gold coatings for wear resistance have shown that the greatest wear resistance is achieved in the case of using DND-FTI-2 (doped with boron) $-0.8 \%$ wear per 22 hours of abrasion. The rest of the additives, explosived into the gold plating, gave almost the same wear $-2.1 \%$ for 22 hours of abrasion.

The studies by atomic force microscopy, both glider methods and electron microscopy, have shown that the additives used affect the surface microstructure, significantly reducing the grain size (Table 2).

From Table 2 it follows that the recommended parameters for applying gold-diamond coating are in the ranges corresponding to the conditions of industrial coating. Thus: 1) the microhardness of gold coatings when using nanodiamonds with a concentration of $1-2 \mathrm{~g} \cdot \mathrm{L}^{-1}$ increases by $50-60 \%$, and in citric acid electrolyte - by $15-20 \%$; 2) the addition of DND-Ioffe-2 in citric acid gilding electrolyte gives a practically wear-free coating.

\subsubsection{Chrome plating}

The authors of [73] investigated the following electrolyte and coating modes: $\mathrm{CrO}_{3}-250 \mathrm{~g} \cdot \mathrm{L}^{-1}$; $\mathrm{H}_{2} \mathrm{SO}_{4}-2.5 \mathrm{~g} \cdot \mathrm{L}^{-1} ; t=45^{\circ} \mathrm{C}, i=50-70 \mathrm{~A} \cdot \mathrm{dm}^{-2}$ (hard chrome plating mode); $t=60{ }^{\circ} \mathrm{C}, i=25-40 \mathrm{~A} \cdot \mathrm{dm}^{-2}$ (wear-resistant chromium plating mode).

Pre-modified DND (modified, MDND). For this purpose, $\mathrm{NH}_{4} \mathrm{NO}_{3}$ was added to the suspension containing DND-TAN, the resulting suspension solution was dried at $105^{\circ} \mathrm{C}$ until water was completely removed, then heated to $215^{\circ} \mathrm{C}$ and held for 2 hours. In this case, $\mathrm{NH}_{4} \mathrm{NO}_{3}$ decomposes to a mixture of nitrogen oxides, the latter interact with the nanodiamond surface, increasing the amount of oxygen-containing functional groups on the surface, and, as a consequence, the hydrophilicity of nanodiamonds. In addition, bonds between nanodiamond particles in aggregates are weakened as a result of exposure to high temperatures and oxidizing gaseous agents.

Table 2. Properties of gold plating with boron modified DND

Electrolyte plated gold

Characteristics

Without additives

With the addition of DND 27-B (boron) -

$1 \mathrm{~g} \cdot \mathrm{L}^{-1}$

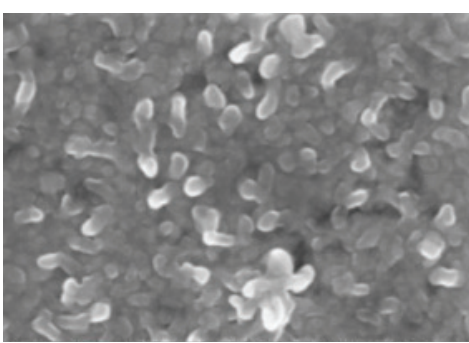

214

1.0 
Sodium hydrogen carbonate or monic acid was successively added to DND powder. When introduced into the water, a violent gas evolution and almost complete "dissolution" of DND occurs, a homogeneous stable suspension of DND in water is formed, which was added to the chromium electrolyte. MDND addition (calculated as pure DND) explosive was added to chromium electrolyte in the following concentrations: $0.1 ; 0.2 ; 0.5 ; 1.5$; $5.0 \mathrm{~g} \cdot \mathrm{L}^{-1}$. When MDND is explosively fed into the electrolyte in an amount of $1 \%$, the content of nanodiamonds in the coating is $0.2 \mathrm{wt} . \%$.

When MDND is added to the electrolyte, the microhardness of chromium coatings increases significantly -1.3 times in the wear-resistant chromium plating mode and 1.6 times in the hard chromium plating mode compared to the microhardness values obtained in pure electrolyte (Fig. 7). With an increase in the content of nanodiamond additives over $1 \mathrm{~g} \cdot \mathrm{L}^{-1}$ in the chromium plating electrolyte, the microhardness values reach a maximum and practically reach a plateau.

Wear resistance was measured only for chrome coatings obtained in the wear-resistant chromium plating mode. It sharply increases $(\sim 2$ times $)$ in comparison with the wear resistance of coatings obtained from pure chromium electrolyte. For a pure chrome coating, the friction coefficient during the experiment varied quite chaotically - from 0.15 to 0.7 . The wear of the sample coated with pure chromium occurs very unevenly, with scuffing, which is not observed when the coating obtained with the addition of the nanodiamond additive MDND is worn.

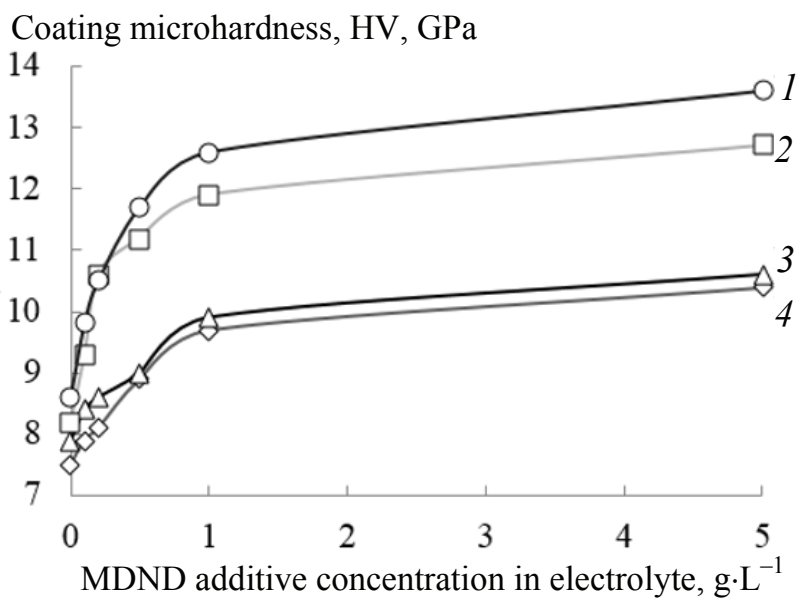

Fig. 7. Dependence of microhardness on the concentration of MDND additive at different current densities for hard chromium [73]:

$1-13.6 \mathrm{GPa}, i=70 \mathrm{~A} / \mathrm{dm}^{2} ; 2-12.7 \mathrm{GPa}, i=65 \mathrm{~A} / \mathrm{dm}^{2}$;

$3-10.6 \mathrm{GPa}, i=60 \mathrm{~A} / \mathrm{dm}^{2} ; 4-10.4 \mathrm{GPa}, i=50 \mathrm{~A} / \mathrm{dm}^{2}$
Thus: 1) a new composite dry DND powder (MDND) has been developed for use in the classic chromium plating electrolyte; 2) the microhardness of the chrome coating increased from 7.8 to $9.6 \mathrm{GPa}$ (by $23 \%$ (wear-resistant chromium plating mode)), and in the hard mode - from 10.4 to $13.6 \mathrm{GPa}$ (by $31 \%$ ); 3) the coefficient of friction of the chromium-diamond coating decreases by 2 times.

\subsubsection{Polymer-diamond composites}

Heat generated by electronic devices and circuits must be dissipated to extend the life of the product. For this, in particular, lubricants (thermoplastic composites, TPC) based on polymers (silicones and epoxy resins) are used to connect the circuits (circuits) in the device itself. TPC have low coefficients of thermoplastic expansion than, for example, aluminum, which is important when TPC contacts with silicon or ceramic circuits. The use of polymeric materials, however, is limited due to their low thermal conductivity $\sim 0.2 \mathrm{~W} \cdot \mathrm{m}^{-1} \cdot \mathrm{K}^{-1}$. As a polymer filler and heat-conducting additives, boron nitride or carbide, aluminum oxide, graphite are used. An increase in the thermal conductivity of TPC due to the extremely high content of the filler is impossible, since with an increase in the concentration of the filler, the mechanical properties of the cured product deteriorate.

So, in the patent [74], the thermal paste contains DND powder, thermal powder and polymer in the ratio of DND - from 5 to $30 \%$ by volume, thermal powder from 40 to $90 \%$ by volume, and polymer from 5 to $30 \%$ by volume DND.

The work [75] describes the production technology and properties of DND-containing TPA. It is shown that such a composite material contains from 0.01 to $80.00 \mathrm{wt} . \%$ DND particles, from 1 to $90 \%$ of at least another filler and from 5 to $80 \mathrm{wt} . \%$ thermoplastic polymer. As the latter, acrylonitrile-butadiene-styrene, acryl, celluloid, cellulose derivatives, cyclic olefin copolymer, ethylene vinyl acetate, ethylene vinyl alcohol, fluoroplastics, or their combinations, a wide range of other polymers are proposed. The polymer can be in crystalline, semi-crystalline or amphora form. The explosive size of the DNDs in TPC is preferably aggregates from 60 to $800 \mathrm{~nm}$. In addition to purified DND, DS is used, preferably containing at least 10 wt.\% non-diamond carbon. The second filler is metal, metal oxides, metal nitrides, carbon in various modifications, and ceramic materials. TPC molding is carried out at an elevated temperature, it is proposed for use in electronic devices and automobiles. Thus, when TPC was obtained from polyphenylene sulfide 
(PPS), the following thermal conductivity results were obtained: pure PPS $-0.21 \mathrm{~W} \cdot \mathrm{m}^{-1} \cdot \mathrm{K}^{-1}$, and with a mixture of nitride boron (40 wt.\%) with DND (5 wt.\%) thermal conductivity increased to $1.41 \mathrm{~W} \cdot \mathrm{m}^{-1} \cdot \mathrm{K}^{-1}$, i.e. 7 times.

When preparing a thermal paste based on polyamide-66 (PA-66) with boron nitride and DND, it was found that even the combined addition of small amounts of DND (0.1 and 0.5 wt.\%) to boron nitride makes it possible to raise the thermal conductivity from $\sim 0.33 \quad$ (PA-66 without additives) up to $4.72 \mathrm{~W} \cdot \mathrm{m}^{-1} \cdot \mathrm{K}^{-1}$, i.e. 14 times.

\subsubsection{DND application of in $3 D$ printing}

For 3D-printers, thermoplastic raw materials are used for layer-by-layer application of molten polymer filament when forming a product. The paper [76] describes the possibility of using DND as a reinforcing filler in such thermal pastes. Were obtained threads from acrylonitrile butadiene styrene (ABS) and from ABS modified with DND (ABS DND). Modification of ABS with 0.05 wt. $\%$ nanodiamonds led to a decrease in friction during extrusion, which made it possible to increase the productivity of the filament manufacturing process. The use of DND additives increased the tensile strength and tensile load of ABS, and the rigidity and elastic modulus also increased. In addition, the thermal conductivity is improved and a higher glass transition temperature of the filament is achieved. The thread contains a thermoplastic polymer in an amount of 80 to $99.99 \mathrm{wt} . \%$ and nanodiamonds in an amount of 0.005 to $10 \mathrm{wt} . \%$, and the thread has at least $15 \%$ higher tensile strength than a thread without DND. The thermal conductivity of the DND filament is at least $8 \%$ higher than the thermal conductivity of the nanodiamond-free filament.

Any suitable thermoplastic polymer can be used: acrylic, celluloid, cellulose acetate, cyclic olefin copolymer, ethylene vinyl acetate, ethylene vinyl alcohol, fluoroplastics such as polytetrafluoroethylene and perfluoroalkoxyalkanes, nylon (aliphatic or aromatic polyethylene (P)), PE), polyethylene terephthalate (PET) and polycarbonate (PC), most preferably polylactic acid. Detonation nanodiamonds can be monofunctionalized with amino, carboxyl, hydrogen, or hydroxyl groups. The DNDs used must have a zeta potential above $+30 \mathrm{mV}$ or below $30 \mathrm{mV}$. The zeta potential is measured in $0.5 \mathrm{wt} . \%$ of an aqueous dispersion of nanodiamond at $\mathrm{pH}=7$. The filament may additionally contain one filler other than DND selected from the group consisting of a metal, a metal oxide, a metal nitride, a metal carbide, a carbon compound, a silicon compound, boron compounds such as boron nitride, ceramic materials, natural fibers or combinations thereof. The thermal conductivity of the article is at least $8 \%$ higher than the thermal conductivity compared to the article without DND. The average tensile strength of the two PLLA (polylactic acid) reference samples is 26.182. The average tensile strength of the two nanodiamond samples is 36.142 . The tensile strength of 3D-printed PLLA material with 0.05 wt. $\%$ aminefunctionalized nanodiamond was improved by $38 \%$.

New 3D-printed products can be used in mechanical engineering, in the aerospace industry, in electronic devices, in the form of polymer compositions to replace existing metal products, as molds, medical devices and materials for the production of artificial bones, etc.

\subsubsection{DND in fuel compositions}

The prospective development of solid rocket propellants requires an increase in energy characteristics. This is achieved by explosive introduction of high-energy components (oxidants, polymeric combustible binders, plasticizers, fillers) into the compositions. Known mixed solid propellant, including an oxidizer - ammonium perchlorate (AP), polyvinyl isoprene rubber with end carboxyl groups, plasticizers - polyvinyl isoprene rubber, curing catalyst - zinc stearate, metallic fuel - dispersed aluminum [77, 78].

A diamond crystal, including detonation nanodiamond (DND), is an example of the densest packing of carbon with a density of $\sim 3.5 \mathrm{~g} \cdot \mathrm{cm}^{-3}$. In $[79,80]$, the possibility of using classical TNThexogen DNDs to increase the combustion rate of model rocket fuels was shown by calculation and experiment. The explosive use of DNDs in the composition of solid rocket fuels (SRF) gives a noticeable increase in the combustion rate of the composition [79, 80], and the effect of their application depends on the component base of the composition and the working pressure in the combustion chamber. A distinctive feature of compositions with DND is a high combustion rate at a low temperature of the combustion products of the composite propellant. In [80], the effect of DND on the combustion rate of a binary mixture of APC-DND with a DND mass content of up to $6 \%$ was studied.

In [81], a modified composite solid rocket fuel (CSRF) is considered, containing an active combustible binder and an oxidizer, while DND co-crystallized with AP is additionally explosive into the fuel with the following total ratio wt.\%: active 
combustible binder 15-30; oxidizing agent 84.5-60.0; detonation nanodiamond $0.5-10.0$. The technical effect consists in increasing the density of the composition and the enthalpy of formation of the fuel and, as a consequence, the energy component, the absence of specific impulse losses for the two-phase flow compared to metal-containing compositions, an increase in gaseous combustion products, and the absence of burnout of the nozzle block in comparison with metal-containing compositions. Calculations performed on the effect of DND on the thermodynamic specific impulse of the reference fuel composition, consisting of $80 \%$ oxidizer - AP, and $20 \%$ active fuel-binder (AFB) for standard conditions at $P_{\mathrm{k}} / P_{\mathrm{a}}=40 / 1\left(P_{\mathrm{k}}\right.$ is the pressure in the combustion chamber, and $P_{\mathrm{a}}$ is the pressure at the nozzle exit) revealed its positive effect on the energy and mass characteristics of the fuel compositions. Explosive treatment in the reference DND composition was carried out by reducing the percentage of PCA, while the content of AFB remained unchanged. Analysis of the calculated data indicates an increase in the density of the composition and temperature in the combustion chamber and, as a consequence, leads to an increase in the specific impulse. With the explosive introduction of each $0.5 \%$ DND into the fuel, the temperature in the combustion chamber increases by an average of $80 \mathrm{~K}$, and the mass specific impulse increases by $2 \mathrm{kgf} \cdot \mathrm{s} \cdot \mathrm{kg}^{-1}$. A further increase in the DND content in the fuel composition leads to a decrease in specific impulse.

Thus, the main advantages of using DND in CSRF compositions are: increasing the density of the composition; an increase in the enthalpy of formation of fuel and, as a consequence, the energy component; loss-free specific impulse due to the two-phase flow in comparison with metal-containing compositions; an increase in the amount of gaseous combustion products; no burnout of the nozzle block in comparison with metal-containing compositions.

\subsubsection{Nanodiamonds in biology and medicine}

The possibility of using DNDs in biology and medicine is determined by their unique properties: a large specific area of crystallites $\sim 300 \mathrm{~m}^{2} \mathrm{~g}^{-1}$ [82], hence the high sorption activity; hydrophilic DND surface; chemical inertness of the diamond core and the activity of the peripheral shell; fluorescence of DND crystallites; the ability of crystallites to penetrate cells; availability of nanodiamonds [39, 83-85]. In addition, DND activity is predetermined by a large number of unpaired electrons $(\sim 40$ per crystallite $\sim 4.8 \mathrm{~nm}$ ) [86]. It has been shown that among the known carbon nanostructures, detonation nanodiamond has the least toxic effect [87, 88]. Therefore, in recent years, the interest of researchers has shifted from known carbon nanostructures to DNDs.

The DND surface covered with primary amino groups is a convenient platform for binding with biomolecules, enzymes, and peptide chains [89]. The relative simplicity of their modification opens up wide possibilities for the direct interaction of nanodiamond crystallites with biological molecules and biological structures, and an increase in the selectivity of DND $[90,91]$.

The most important for use in biology is the specific binding of DND to proteins, both covalent [92] and non-covalent [93]. The advantages of the covalent attachment of biological macromolecules to the nanodiamond surface are the high stability of the adduct, provided by strong covalent bonds rather than electrostatic interactions (for example, with peptides [94]). However, non-covalent modification also has its advantages, in particular, when creating drug delivery systems [95]. The modification of the DND surface with proteins opens up the possibility of creating biochips based on nanodiamond, since the actual immobilization of proteins on a diamond substrate is one of the critical stages in the creation of biochips [96-98], while the most important is the chemical and physical stability of diamonds, which ensures high strength of the substrate. Diamond particles containing color centers - fluorescent crystallographic defects embedded in the diamond lattice - outperform other classes of fluorophores, providing a combination of photostability, internal biocompatibility and significant mechanical and chemical resistance, emitting in the UV, visible and IR spectral regions with exceptional photostability even at high temperature. This exceptional combination of properties positions fluorescent diamond particles as unique fluorophores with new potential applications in a variety of fields, including bioimaging, supersensitive metrology at the nanoscale, fluorescent labels in industrial applications, and even potentially as contrast agents for magnetic resonance imaging.

One of the main areas of application of fluorescent nanodiamonds is focused on bioimaging and biosensors. In the field of bioimaging, there is still an unmet need for extremely bright, photostable, non-toxic particles of a few nanometers in size with radiation in the red (near infrared) range. DNDs containing nitrogen vacant centers exhibit strong fluorescence sufficient to observe a single particle in 
a cell, and the fluorescence does not disappear within $300 \mathrm{~s}$, for ordinary chemical dyes this time is $10 \mathrm{~s}$ [7]. The advantage of such DNDs is that they emit light in the red region of the spectrum $(575-750 \mathrm{~nm})$, which makes it possible to work outside the region where intrinsic cell fluorescence is observed $(300-500 \mathrm{~nm})$ [99]. Moreover, these emitters are photostable [100-102]. DND fluorescence can also be caused by the presence of vacant silicon complexes (SiV) $[103,104]$. A convenient method for observing the behavior of DND is the method of radioactive labels. In [105], the preparation of tritium-labeled DNDs and their application in tissues and organisms are described.

The relative ease of DND penetration into cells has made it possible to successfully deliver various drugs immobilized on the surface into the cell, while the substances retain their natural activity [89, 92]. For example, due to ionic bonds, DNDs form adducts with the anticancer drug doxorubicin [106]. It was shown in [107] that neural stem cells can be successfully grown on the hydrophilic surface of DND.

Thus, the possible use of DNDs as fluorescent objects in cells is an alternative to toxic quantum dots. In addition, DNDs can be used in in vitro systems, for example, for the delivery of drugs into cells, with the creation of various diagnostic systems based on DNDs. The adsorption capacity of nanodiamonds opens up prospects for the creation of enterosorbents. The ability to deliver genes using DND allows them to be used for genetic engineering. Given the non-toxicity and biocompatibility of nanodiamonds, they are already used in compositions for external use, for example, in cosmetics.

Modern methods of cancer treatment have a number of limitations associated with the presence of serious toxic and side effects of chemotherapy, radiation therapy, and targeted therapy with antibodies at terminal stages of cancer development $[1,7]$. The use of DND opens up new possibilities for the simultaneous detection and treatment of cancer. The size of DND is comparable to biological macromolecules such as proteins, enzymes, and DND plasmids [4]. Consequently, DNDs can penetrate cell membranes, presumably during endocytosis [7], which allows them to act as drug carriers. The nanosized DNDs also allow them to penetrate and selectively accumulate in tumors at much higher concentrations than in surrounding healthy tissue.

The study [108] was devoted to the sorption / desorption of nuclear medical isotopes technetium, bismuth, yttrium, and radium on DND for potential use as carriers for their targeted delivery. For this purpose, the adsorption properties of Tc (VII, IV),
Bi (III), Y (III), and Ra (II) were studied using industrial DND samples. The choice of isotopes was determined not only by their wide range of applications, but also by the difference in their chemical properties. It was found that DND adsorb up to $90 \%$ of Tc (VII), but its quantitative desorption occurs in physiological solution. Tc (IV) is efficiently sorbed by the oxidized DND surface by more than $90 \%$, and its desorption in a solution of bovine serum albumin dissolved in phosphate-buffered saline (BSA in PBS) does not exceed $5 \%$. This allows the studied DNDs with oxygen-containing groups on their surface to be used for targeted delivery of Tc (IV). The adsorption of Bi (III) on the studied DNDs varied from 80 to $100 \%$, while its desorption in BSA in PBS for DND, DND-COOH did not exceed $10 \%$, and for DND without oxygencontaining groups - up to $30 \%$. It was shown that the kinetics of sorption of $\mathrm{Y}$ (III) proceeds more slowly than for Bi (III). Desorption of Bi (III) in a BSA solution in PBS for $1 \mathrm{~h}$ rose to $35 \%$ from the DND surface.

Within $48 \mathrm{~h}$, the biodistribution of DND with a particle size of 2-8 $\mathrm{nm}$ and a purity of more than $95 \%$ was investigated using the radioactive isotope ${ }^{188} \mathrm{Re}$ during intracheal explosive feeding of mice [109]. It was found that DNDs are distributed in the spleen, liver, bones and heart with maximum accumulation in the lungs.

For 28 days, the toxicity, accumulation and excretion from the lungs of DND (particle size $5 \mathrm{~nm}$ ) and fragmented synthetic nanodiamond (particle size $50 \mathrm{~nm}$ ) were studied during their intracheal explosive treatment [110]. Based on histopathological and ultrastructural studies, it was concluded that nanodiamonds did not have obvious negative effects on lung tissue during the entire study period. Their excretion from the lungs is associated with their absorption by alveolar macrophages and their subsequent clearance into the trachea and then into the pharynx.

DND is removed from all organs within almost 1 month. This opens up additional possibilities for the use of DND in pharmaceutical practice for the development of prolonged dosage forms. It is fundamentally important that DND particles penetrate the brain, overcoming the blood-brain barrier. Thus, there is a fundamental possibility of developing promising drugs based on DND for the treatment of diseases of the central nervous system.

The first researcher to suggest the use of DND in medicine was V.Yu. Dolmatov [111]. He found that DNDs are highly active against pathogenic viruses, microbes and bacteria and can be used as an 
enterosorbent (adsorbent in vivo) [111]. The cytotoxicity of DND was also studied, which showed its good biocompatibility in such different cell cultures as human lung adenocarcinoma cells [112]; HeLa cells (human cervical carcinoma) [113]; neuroblastoma cells [114]; macrophages [114]; neutrophils [115].

Investigated [116] the effect of DND on 6 types of human cells (cells of the lungs, kidneys, colon, liver). It has been shown that DNDs with particle sizes of 20 and $100 \mathrm{~nm}$ enter cells efficiently and do not cause any cytotoxic or genotoxic effects up to a concentration of $500 \mu \mathrm{g} \cdot \mathrm{m}^{-1}$. By itself, nanodiamonds (oxidized form) are able to suppress the development of Alzheimer's disease (experiments on rats) [117].

In the only work [118], the acute toxicity of DND was studied and the LD50 value (mice, peros) was determined to be more than $7.5 \mathrm{~g} \cdot \mathrm{kg}^{-1}$.

The creation of anticancer dosage forms based on nanodiamond was studied in [119]. Two anticancer drugs have been investigated - paclitaxel (a mitosis blocker) and cetuximab, which enhances mitotic catastrophe and slows tumor growth in human colorectal cancer. Pure nanodiamond had no effect on the growth of cancer cells. The DND sample paclitaxel - cetuximab was also effective in inhibiting the growth of tumor cells. Thus, it has been shown that nanodiamonds are a promising carrier for the development of new dosage forms in cancer therapy.

It was found that the system nanodiamond cetuximab - cisplatin can significantly inhibit the growth of hepatocellular liver carcinoma cells, and the therapeutic activity of this system turned out to be better than that of the nonspecific nanodiamond cisplatin conjugate.

The amount of adsorption of amikacin on DND depends on the nature of the surface functional groups. Thus, for oxidized and hydrogenated DND, the value of the maximum equilibrium adsorption of amikacin was 130 and $50 \mathrm{mg} \cdot \mathrm{g}^{-1}$, respectively. In this case, the amount of irreversibly sorbed antibiotic was 48 and $22 \mathrm{mg} \cdot \mathrm{g}^{-1}$, respectively.

DND-surface-bound paclitaxel, as well as unbound paclitaxel, is an effective inducer of lung carcinoma cell death, which confirms the preservation of drug efficiency after its immobilization on DND.

The covalent attachment to the surface of nanodiamond-anticancer drug amonafid was studied [120]. The resulting conjugates have been shown to be effective in the treatment of breast cancer.

It was noted [121, 122] that the use of DND suspension facilitates the condition of cancer patients, apparently due to a decrease in the level of intoxication of the body. In addition, DND has been used as a means of correcting the processes of protein and lipid peroxidation during the growth of malignant neoplasms.

Currently, DNDs are the subject of intensive research aimed at improving the delivery of low molecular weight substances and biotechnological products, and especially chemotherapeutic agents.

\section{Conclusion}

In this review, the authors analyzed information on the synthesis and application of detonation nanodiamonds, namely:

- an assumption was made about the fractal principle of the formation of DND infrastructure in the zone of chemical reactions during the EM explosion;

- the distance of formation of DND particles from the beginning of the detonation wave front in EM is determined $-1 / 3-3 / 4$ of the charge diameter;

- it was found that at the output of DND 6 wt.\% and more for the formation of nanodiamonds is $(20 \pm 2) \%$ of carbon EM;

- an insignificant probability of the formation of nitrogen-free DNDs is shown, the optimal range of nitrogen concentration in EM molecules (23-28 wt.\%) has been determined to obtain DND yield from 6 wt. $\%$ and more;

- the possibility of predicting the range of the DND output depending on the detonation velocity, specific power EM and pressure in the ChapmanJouguet plane is shown;

- found that the most preferred individual EM for obtaining DND with a yield of 6-7 wt.\% is tetryl, binary mixtures based on tetryl give a nanodiamond yield up to $7.3 \mathrm{wt} . \%$, and ternary - up to $8.2 \mathrm{wt.} \%$;

- the range of $\mathrm{HNO}_{3}$ concentration and temperature for selective oxidation of the diamond charge to a given ratio of diamond and graphite phases at a temperature of $120-230{ }^{\circ} \mathrm{C}$ has been established;

- DND was characterized by IR-spectroscopy data;

- according to EPR and NMR data, it was shown that the size and structure of DND from tetryl is similar to nanodiamonds from an alloy of TNT with RDX or a ternary mixture of tetryl, RDX and TNT, which indicates a single mechanism for the formation of DND nanocrystallites;

- the features of EPR spectroscopy on nonoriented samples, which include diamond polycrystals, including DND samples, are described. The main parameters characterizing the lines in the EPR spectra are described. The sources of magnetism 
in diamond samples are considered in detail. All known types of magnetic defects in DNDs are considered, including their origin and localization. Particular attention is paid to triplet centers in the DND, which include $\mathrm{N}-\mathrm{V}$ centers and multivacancies detected at half magnetic field values (region $g=4$ ). It was shown that EPR reliably indicates an increase in the content of triplet centers of the $N-V$-type in DND samples irradiated with electron beams.

- electrochemical gilding with DND leads to a practical absence of wear when using boron-doped DND, an increase in microhardness by $20-60 \%$ (up to $220 \mathrm{~kg} \cdot \mathrm{mm}^{-2}$ ), it is recommended to reduce the thickness of the gold coating by 2-3 times;

- during joint electrochemical chromium plating in the presence of DND-TAN doped with phosphorus and boron DND, shiny, smooth uniform coatings are deposited, the microhardness increases from 855 to $1300 \mathrm{~kg} \cdot \mathrm{mm}^{-2}$;

- it is shown that the addition of DND from 0.1 to 5.0 wt. $\%$ in thermal paste can raise their thermal conductivity by $7-14$ times (up to $4.72 \mathrm{~W} \cdot \mathrm{m}^{-1} \cdot \mathrm{K}^{-1}$ ).

The possibility of using DND for polymer filaments of 3D-printers even in an amount of 0.05 wt.\%, which leads to an increase in tensile strength by $38 \%$ (polylactic acid), a friction decrease during extrusion (the productivity of filament deposition increased up to 10 times), raised rigidity and elastic modulus of the product. The explosive content of nanodiamonds in fuel compositions increases the amount of gaseous combustion products, there is no flare up of the engine nozzle, every $0.5 \mathrm{wt} . \%$ DNDs increase the temperature in the combustion chamber by $80 \mathrm{~K}$, and the mass specific impulse increases by $2 \mathrm{~kg} \cdot \mathrm{s} \cdot \mathrm{kg}^{-1}$.

It has been shown that DNDs are an alternative to toxic quantum dots. Nanodiamonds can be used to deliver drugs to the cells of the body; they selectively accumulate in cancerous tumors in high concentrations. DNDs are also promising enterosorbents. When explosively ingested into the body, nanodiamonds are distributed in the spleen, liver, bones, heart, with the maximum amount in the lungs. DND particles penetrate into the brain, overcoming the blood-brain barrier. DNDs effectively enter human cells without causing any cytotoxic or genotoxic effects up to a concentration of $500 \mathrm{mg} \cdot \mathrm{mL}^{-1}$.

\section{Funding}

This study was partially funded by the Russian Foundation for Basic Research within the framework of research project No. 18-29-19112.

\section{Conflict of interests}

The authors declare no conflict of interest.

\section{References}

1. Dolmatov VYu. Detonation synthesis nanodiamonds: synthesis, structure, properties and applications. St. Petersburg: NPO Professional; 2011. 536 p. DOI:10.1070/RC2007v076n04ABEH003643 (In Russ.)

2. Dolmatov VYu, Malygin AA, Dorokhov AO, Kozlov AS, Marchukov VA, Suschev VG, Myllymäki V, Vehanen A. Development of a process for producing detonation nanodiamonds from tetryl and binary compositions based on it. Journal of Superhard Materials. 2020;42(3):145-156. DOI:10.3103/ S1063457620030053

3. Vul AYa, Shenderova O. (eds.) Detonation nanodiamonds - science and applications. New York: Jenny Stanford Publ.; 2014, 346 p. DOI:10.1201/b15541

4. Shenderova O, Gruen D. (eds.) Ultrananocrystalline diamond, synthesis, properties, and application. Kidlington-Norwich: William Andrew Publ.; 2006, 611 p.

5. Lisichkin GV, Olenin AYu, Kulakova II. Modification of the surface of inorganic nanoparticles. Moscow: Technosphere; 2020, 394 p. (In Russ.)

6. Khrapkovsky GM, Chachkov DV, Nikolaeva EV, Gaisin IS, Shamov AG. Internet conference "Butlerov Readings". Available from: http://butlerov.com/ readings/ [Accessed 11 March 2019] (In Russ.)

7. Vul AYa, Shenderova OA (ed.) Detonation nanodiamonds. Technology, structure, properties and applications: Collection of articles. St. Petersburg: Ioffe Institute Publ.; 2016, 381 p. (In Russ.)

8. Kulakova II. Surface chemistry of nanodiamonds. Physics of the Solid State. 2004;46(4):636-643. DOI:10.1134/1.1711440

9. Danilenko VV. Explosion: physics, engineering, technology. Moscow: Energoatomizdat; 2010, 784 p. (In Russ.)

10. VanThiel M, Ree FH. Properties of carbon clusters in TNT detonation products: Graphite-diamond transition. Journal of Applied Physics. 1987;62(5):1761. DOI:10.1063/1.339575

11. Dremin AN, Pershin SV, Pyaternev SV, Tsaplin DN. Kink in the dependence of the detonation velocity on the initial TNT density. Fizika goreniya $i$ vzryva = Combustion, Explosion, and Shock Waves. 1989;25(5):141-144. (In Russ.)

12. Antipenko AG, Pershin SV, Tsaplin DN. In the book. IX All-union symposium on combustion and explosion. Chernogolovka: FRCCP RAS Publ.; 1989. 104 p. (In Russ.)

13. Pershin SV, Tsaplin DN, Antipenko AG. On the possibility of diamond formation during tetrile 
detonation. In coll. of reports of $V$ All-union detonation meetings. Chernogolovka: IMTECH Publishing House; 1991. p. 233-236. (In Russ.)

14. Pershin SV, Tsaplin DN. Dynamic research of detonation synthesis of dense phases of matter. In coll. of reports of $V$ All-union detonation meetings. Chernogolovka: IMTECH Publishing House; 1991. p. 237-244 (In Russ.)

15. Loboiko BG, Lyubyatinsky NS. Reaction zones of detonating solid explosives, Combustion, explosion, and shock waves. 2000;36(6):716-733. DOI:10.1134/ S0010508214020166

16. Dremin AN, Shvedov KK. Determination of Chapman-Jouguet pressure and reaction time in a powerful explosive detonation wave. Zhurnal prikladnoy mekhaniki $i$ tekhnicheskoy fiziki = Journal of Applied Mechanics and Technical Physics. 1964;2:154-159. (In Russ.)

17. Dolmatov VYu, Myllymaki V, Vehanen A. A possible mechanism of nanodiamond formation during detonation synthesis. Journal of Superhard Materials. 2013;35(3):143-150. DOI:10.3103/ S1063457613030039

18. Aleshaev AN, Zubkov PI, Kulipanov GN, Luk'yanchikov LA, Lyakhov NZ, Mishnev SI, Ten KA, Titov VM, Tolochko BP, Fedotov MG, Sheromov MA. Application of synchrotron radiation for studying detonation and shock-wave processes. Combustion Explosion and Shock Waves. 2001;37(5):585-593. DOI:10.1023/A:1012353406187

19. Titov VM, Tolochko BP, Ten KA, Lukyanchikov LA, Pruuel ER. Where and when are nanodiamonds formed under explosion. Diamond and Related Materials. 2007;16(12):2009-2013. DOI:10.1016/j.diamond.2007.09.001

20. Dolmatov VYu, Dorokhov AO, Mullyumaki V, Vekhanen A, Marchukov VA. The zone of chemical reactions in the detonation synthesis of nanodiamonds in the phase diagram of carbon. XXII Int. conference "Rock-cutting and metal-working tools-equipment and technology for its manufacture and application": Coll. of scientific papers. Kiev: V. Bakul Institute for Superhard Materials; 2019;22:199-204. (In Russ.)

21. Dolmatov VYu, Dorokhov AO, Kozlov AS, Marchukov VA, Myllymäki V, Vehanen A. Possibility of predictive estimation of DND yield from individual explosives. Journal of Superhard Materials. 2021;2:1-8.

22. Dolmatov VYu. On the possibility of obtaining nitrogen-free detonation nanodiamonds: effect of covalently bound nitrogen in explosive molecules on the yield of nanodiamonds. Journal of Superhard Materials. 2020;42(4):223-228. DOI:10.3103/S1063457620040036

23. Sattler KD. Carbon nanomaterials sourcebook: graphene, fullerenes, nanotubes and nanodiamonds. Vol. I. USA: CRC Press Taylor \& Francis Group; 2016. 614 p.

24. Dolmatov VYu. The influence of detonation synthesis conditions on the yield of condensed carbon and detonation nanodiamond through the example of using TNT-RDX explosive mixture. Journal of Superhard Materials. 2018;40(4):290-294. DOI:10.3103/S1063457618040093

25. Dolmatov VYu. Diamond-carbon material and a method for the production thereof. United States patent 7,862,792. 4 January 2011.

26. Nesvizhevsky V, Koster U, Dubois M, Batisse N, Frezet L, Bosak A, Gines L, Williams O. Fluorinated nanodiamonds as unique neutron reflector. Carbon. 2018;130:799-805. DOI:10.1016/j.carbon.2018.01.086

27. Kulakova II, Korol'kov VV, Yakovlev RYu, Lisichkin GV. The structure of chemically modified detonation-synthesized nanodiamond particles. Nanotechnologies in Russia. 2010;5:474-485. DOI:10.1134/S1995078010070074

28. Petrov EA, Baraboshkin KS, Bychin NV, Larionov BV., Bayramyan IV. Study of TNAB for the detonation synthesis of nanodiamonds. VI Staverovsky readings: ultradispersed powders, nanostructures, materials: Proceedings of the All-Russian scientific and technical conference with international participation, dedicated to the 30th anniversary of the discovery of nanodiamonds, 9-12 September 2012. Biysk, Gornyy Altay: Naukograd; 2012. p.14-15. (In Russ.)

29. Dolmatov VYu, Myllymäki V, Vehanen A, Dorokhov AO, Kiselev MN. Dependence of the detonation nanodiamond yield on the detonation process parameters. Journal of Superhard Materials. 2019;41(5):1-5. DOI:10.3103/S1063457619050071

30. Petrov EA. Investigation of physicochemical processes of detonation synthesis of nanodiamonds. In Col. of report International scientific, technical and methodological conference. Kazan: KNRTU Publ.; 2004. p. 881-888. (In Russ.)

31. Dorokhov AO, Dolmatov VYu, Malygin AA, Kozlov AS, Marchukov VA. Development of the detonation nanodiamond synthesis from tetryl based ternary mixtures. Russian Journal of Applied Chemistry. 2020;93(7):1083-1089. DOI:10.1134/S1070427220070204

32. Panich AM, Shames AI, Mogilyansky D, Goren SD, Dolmatov VYu. Detonation nanodiamonds fabricated from tetryl: Synthesis, NMR, EPR and XRD study. Diamond and Related Materials. 2020;108:107918. DOI:10.1016/j.diamond.2020.107918

33. Marchukov VA, Kolodyazhny AL, Makarov IA, Korolev KM, Suschev VG. Method for cleaning detonation nanodispersed diamonds. Russian Federation Patent 2,599,665. 10 October 2016. (In Russ.)

34. Sushchev VG, Dolmatov VYu, Malygin AA, Marchukov VA, Korolev KM, Dorokhov AO. CoreShell composites based on partially oxidized blend of detonation synthesis nanodiamonds. Russian Journal of Applied Chemistry. 2020;93(5):660-670. DOI:10.1134/ S1070427220050067

35. Yakovlev RY, Dogadkin NN, Kulakova II, Lisichkin GV, Leonidov NB, Kolotov VP. Determination of impurities in detonation 
nanodiamonds by gamma activation analysis method. Diamond and Related Materials. 2015;55:77-86. DOI:10.1016/j.diamond.2015.03.010

36. Volkov DS, Proskurnin MA, Korobov MV. Elemental analysis of nanodiamonds by inductivelycoupled plasma atomic emission spectroscopy. Carbon. 2014;74:1-13. DOI:10.1016/j.carbon.2014.02.072

37. Korobov MV, Volkov DS, Avramenko NV, Belyaeva LA, Semenyuk PI, Proskurnin MA. Improving the dispersity of detonation nanodiamond: differential scanning calorimetry as a new method of controlling the aggregation state of nanodiamond powders. Nanoscale. 2013;5(4):1529-1536. DOI:10.1039/c2nr33512c

38. Volkov DS, Proskurnin MA, Korobov MV. Survey study of mercury determination in detonation nanodiamonds by pyrolysis flameless atomic absorption spectroscopy. Diamond and Related Materials. 2014;50:60-65. DOI:10.1016/j.diamond.2014.08.013

39. Dolmatov VYu, Ozerin AN, Kulakova II, Bochechka OO, Lapchuk NM, Myllymäki V, Vehanen A. Detonation nanodiamonds: new aspects in the theory and practice of synthesis, properties and applications. Russian Chemical Reviews. 2020;89(12):1428-1462, DOI:10.1070/RCR4924

40. Kulakova II, Korol'kov VV, Yakovlev RYu, Lisichkin GV. The structure of chemically modified detonation synthesized nanodiamond particles. Nanotechnologies in Russia. 2010;5(7-8):474-485. DOI:10.1134/S1995078010070074

41. Vereshcagin AL, Yur'ev GS. Structure of detonation diamond nanoparticles. Inorganic Materials. 2003;3(3):247-253. DOI:10.1023/A:1022621407325

42. Dolmatov VY. On the structure of detonation nanodiamond cluster. Journal of Superhard Materials. 2005:28.

43. Yur'ev GS, Dolmatov VYu. X-Ray diffraction study of detonation nanodiamonds. Journal of Superhard Materials. 2010;32(5):311-328. DOI:10.3103/S1063457610050035

44. Ţucureanu V, Matei A, Avram AM. FTIR spectroscopy for carbon family study. Critical Reviews in Analytical Chemistry. 2016;46:502-520. DOI:10.1080/10408347.2016.1157013

45. Petit T, Puskar L. FTIR spectroscopy of nanodiamonds: Methods and interpretation. Diamond and Related Materials. 2018;89:52-66. DOI:10.1016/ j.diamond.2018.08.005

46. Tsubota T, Urabe K, Egawa S, Hirabayashi O, Takagi H, Kusakabe K, Morooka H, Maeda H. Surface modification of hybrogenated diamond powder by radical reactions in chloroform solutions. Diamond and Related Materials. 2000;9:219-223. DOI:10.1016/S0925-9635(00)00234-X

47. Ando T, Rawles RE, Yamamoto K, Kamo M, Sato Y, Nishitani-Gamo M. Chemical modification of diamond surfaces using a chlorinated surface as an intermediate state. Diamond and Related Materials. 1996;5:1136.

48. Liang YJ, Ozawa M, Krueger A. A general procedure to functionalize agglomerating nanoparticles demonstrated on nanodiamond. ACS Nano. 2009;3:2288-2296. DOI:10.1021/nn900339s

49. Zheng WW, Hsieh Y-H, Chiu Y-C, Cai S-J, Cheng CL, Chen C. Organic functionalization of ultradispersed nanodiamond: synthesis and applications. Journal of Materials Chemistry. 2009;19(44):8432. DOI:10.1039/B904302K

50. Christiaens P, Vermeeren V, Wenmackers S. EDC-mediated DND attachment to nanocrystalline CVD diamond films. Biosensors \& Bioelectronics. 2006;22(2):170-177. DOI:10.1016/j.bios.2005.12.013

51. Koscheev AP. Thermal desorption mass spectrometry in the light of solving the certification and unification problem of the surface properties of detonation nanodiamonds. Rossiyskiy Khimicheskiy Zhurnal = Russian Journal of General Chemistry. 2008;52(5):88-96. (In Russ.)

52. Weil JA, Bolton JR. Electron paramagnetic resonance: elementary theory and practical applications. New York: Wiley; 2007. 688 p.

53. Baranov PG, von Bardeleben H-J, Jelezko F, Wrachtrup J. Magnetic resonance of semiconductors and their nanostructures: basic and advanced applications. Austria: Springer-Verlag GmbH; 2019. $539 \mathrm{p}$.

54. Duer MJ. Solid state NMR spectroscopy: principles and applications. Oxford: Wiley; 2008. $592 \mathrm{p}$.

55. Shames AI, Osipov VYu, Boudou JP, Panich AM, von Bardeleben H-J, Treussart F, Vul' AYa. Magnetic resonance tracking of fluorescent nanodiamond fabrication. Journal of Physics D: Applied Physics. 2015;48(15):1-13. DOI:10.1088/00223727/48/15/155302

56. Casabianca LB, Shames AI, Panich AM, Shenderova O, Frydman L. Factors affecting DNP NMR in polycrystalline diamond samples. Magnetic resonance tracking of fluorescent nanodiamond fabrication. Journal of Physical Chemistry C. 2011;115(39):19041-19048. DOI:10.1021/jp206167j

57. Shames AI, Mogilyansky D, Panich AM, Sergeev NA, Olszewski M, Boudou J-P, Osipov VYu. $\mathrm{XRD}$, NMR, and EPR study of polycrystalline microand nano-diamonds prepared by a shock wave compression method. Physica Status Solidi A. 2015;212(11):2400-2409. DOI:10.1002/pssa.201532154

58. Shames AI, Panich AM, Kempinski W, Alexenskii AE, Baidakova MV, Dideikin AT, Osipov VYu, Siklitski VI, Osawa E, Ozawa M, Vul' AYa. Defects and impurities in nanodiamonds: EPR, NMR and TEM Study. Journal of Physics and Chemistry of Solids. 2002;63(11):1993-2001. DOI:10.1016/S00223697(02)00185-3

59. Osipov VYu, Shames AI, Enoki T, Takai K, Baidakova MV, Vul' AYa. Paramagnetic defects and exchange coupled spins in pristine ultrananocrystalline diamonds. Diamond and Related Materials. 2007;16(12):2035-2038. DOI:10.1016/j.diamond.2007.06.003 
60. Shames AI, Panich AM, Osipov VYu, Aleksenskiy AE, Vul' AYa, Enoki T, Takai K. Structure and magnetic properties of detonation nanodiamond chemically modified by copper. Journal of Applied Physics. 2010; 107(1):0143181,1-10. DOI:10.1063/1.3273486

61. Terada D, Segawa TF, Shames AI, Onoda S, Ohshima T, Ōsawa E, Igarashi R, Shirakawa M. Monodisperse five-nanometer-sized detonation nanodiamonds enriched in nitrogen-vacancy centers. ACS Nano. 2019;13(6):6461-6468. DOI:10.1021/acsnano.8b09383

62. Shames AI, Osipov VYu, Aleksenskiy AE, Ōsawa E, Vul' AYa. Locating inherent unpaired orbital spins in detonation nanodiamonds through the targeted surface decoration by paramagnetic probes. Diamond and Related Materials. 2011;20(3):318-321. DOI:10.1016/j.diamond.2011.01.007

63. Panich AM, Shames AI, Sergeev NA, Osipov VYu, Alexenskiy AE, Vul' AYa. Magnetic resonance study of gadolinium-grafted nanodiamonds. Journal of Physical Chemistry C. 2016;120(35):19804-19811. DOI:10.1021/acs.jpcc.6b05403

64. Panich AM, Salti M, Goren SD, Yudina EB, Aleksenskii AE, Vul' AYa, Shames AI. Gd(III)-grafted detonation nanodiamonds for MRI contrast enhancement. Journal of Physical Chemistry C. 2019;123(4):2627-2631. DOI:10.1021/acs.jpcc.8b11655

65. Panich AM, Sergeev NA. Shames AI, Osipov VYu, Boudou J-P, Goren SD. Size dependence of $13 \mathrm{C}$ nuclear spin-lattice relaxation in micro- and nanodiamonds. Journal of Physics: Condensed Matter. 2015;27(7):072203,1-7. DOI:10.1088/0953-8984/27/7/ 072203

66. Zegrya GG, Samosvat DM, Osipov VYu, Vul' AYa, Shames AI. Size effect in electron paramagnetic resonance spectra of impurity centers in diamond nanoparticles. arXiv:1912.06330. 2019; Available from: https://arxiv.org/abs/1912.06330

67. Shames AI, Osipov VYu, von Bardeleben H-J, Vul' AYa. Spin $S=1$ centers: a universal type of paramagnetic defects in nanodiamonds of dynamic synthesis. Journal of Physics: Condensed Matter. 2012;24(22):225302,1-8. DOI:10.1088/0953-8984/24/ $22 / 225302$

68. Shames AI, Osipov VYu, von Bardeleben H-J, Boudou J-P, Treussart F, Vul' AYa. Native and induced triplet nitrogen-vacancy centers in nano- and micro- diamonds: Half-field electron paramagnetic resonance fingerprint. Applied Physics Letters. 2014;104(10):063107,1-5. DOI:10.1063/1.4865205

69. Shames AI, Smirnov AI, Milikisiyants S, Danilov EO, Nunn N, McGuire G, Torelli MD, Shenderova O. Fluence-dependent evolution of paramagnetic triplet centers in e-beam irradiated microcrystalline Ib type HPHT diamond. Journal of Physical Chemistry C. 2017;121(40):22335-22346. DOI:10.1021/acs.jpcc.7b06514
70. Dolmatov VYu, Rudenko DV, Burkat GK, Aleksandrova AS, Vul AYu, Aleksenskii AE, Kozlov AS, Myllymäki V, Vehanen A, D'yakov IA, Dorokhov AO, Kiselev MN. A study of the process of gold plating from citrate and phosphate electrolytes in the presence of modified detonation nanodiamonds. Journal of Superhard Materials. 2019;41(3):169-177. DOI:10.3103/S1063457619030043

71. Ōsawa E. Recent progress and perspectives in single-digit nanodiamond. Related Materials. 2007;16:2018-2022. DOI:10.1016/j.diamond.2007.08.008

72. Aleksenskiy AE, Vul AYa, Didykin AT. A method for producing an aqueous suspension of detonation nanodiamonds. Russian Federation patent 2,446,097. 14 September 2010. (In Russ.)

73. Dolmatov VYu, Burkat GK, Svir KA, Marchukov VA, Dorokhov AO, Vehanen A, Myllymaki V, Kozlov AS, Almazova NS. Study of electrochemical deposition process of chromium in the presence of composite diamond-containing compound. Tooling materials science, Collection of Scientific Papers. 2020;23:187-194.

74. Lu H-T, Uvarov S. Nanodiamond thermal grease. United States patent 2010/0022423 A1. 28 January 2010.

75. Myllymaki V, Syren J. Nanodiamonds containing thermoplastic thermal composites. United States patent 20150259591. 17 September 2015.

76. Myllymäki V, Larson SCh. A filament and $3 D$ printed item. Patent EP 3,502,324. 26 July 2019.

77. Kutsenko GV, Okhrimenko EF, Khimenko LL, Fedotov IA, Kozintseva LG, Pyankova EE. Mixed solid propellant. Russian Federation patent 2,430,902. 10 October 2011. (In Russ.)

78. Egorychev VS, Kondrusev VS. Chemical rocket engine fuels. Samara: Samara University Publ.; 2007. 72 p. (In Russ.)

79. Golubev AA, Gorbachev VA, Shevchenko NV, Ubeiy-Volk EYu. Detonation nanodiamond as prospective component of composite solid propellants. Izvestiya Vysshikh Uchebnykh Zavedenii, Seriya Khimiya $i$ Khimicheskaya Tekhnologiya = ChemChemTech. 2016;59(8):96-100. DOI:10.6060/tcct.20165908.37y (In Russ.)

80. Shevchenko NV, Gorbachev VA, Ubej-Volk EYu, Danilenko VV, Blank VD, Golubev AA, Deribas AA. Influence of detonation nanodiamonds on the combustion of energy-intensive rocket fuel compositions. Konstruktsii iz kompozitsionnykh materialov = Composite structures. 2014;3(135):33-39. (In Russ.)

81. Gorbachev VA, Ubej-Volk EYu, Shevchenko NV. Fuel composition. Russian Federation patent 2,649,573. 04 April 2018. (In Russ.)

82. Jee A-Y, Lee V. Surface functionalization and physicochemical characterization of diamond nanoparticles. Current Applied Physics. 2009;9:144-147. DOI:10.1134/S1070363212130117 
83. Krueger A. Diamond nanoparticles: jewels for chemistry and physics. Advanced Materials. 2008;20:2445-2449. DOI:10.1002/adma.200701856

84. Mochalin V, Osswald S, Gogotsi Y. Contribution of functional groups to the Raman spectrum of nanodiamond powders. Chemistry of Materials. 2009;21:3728-3735. DOI:10.1021/cm802057q

85. Osswald S, Yushin G, Mochalin V, Kusheyev $\mathrm{SO}$, Gogotsi Y. Control of $\mathrm{sp}^{2} / \mathrm{sp}^{3}$ carbon ratio and surface chemistry of nanodiamonds powders by selective oxidation in air. Journal of the American Chemical Society. 2006;128(35):11635-11642. DOI:10.1021/ja063303n

86. Fang XW, Mao JD, Levin EM, Schmidt-Rohr K. Nonaromatic core-shell structure of nanodiamond from solid-state NMR spectroscopy. Journal of the American Chemical Society. 2009;131(4):517-526. DOI:10.1021/ja8054063

87. Piotrovsky LB, Kiselev OI. Fullerenes in biology. St. Petersburg: Rostock; 2006. 335 p.

88. Keservani RK, Sharma AK. (eds.) Nanoparticulate drug delivery systems. Toronto: Apple Academic Press; 2019. p. 4-5.

89. Chao J-I, Perevedentseva E, Chung PH, Liu KK, Cheng CY, Chang CC, Cheng CL. Nanometersized diamond particle as a probe for biolabeling. Biophysical Journal. 2007;93:2199-2208. DOI:10.1529/biophysj.107.108134

90. Spitsyn BV, Davidson JL, Gradoboev MN, Galushko TB, Serebryakova NV, Karpukhina TA, Kulakova II, Melnik NN. Inroad to modification of detonation nanodiamond. Diamond and Related Materials. 2006;15:296-299. DOI:10.1016/j.diamond.2005.07.033

91. Tsubota T, Tanii S, Ida S, Nagata $M$, Matsumoto Y. Chemical modification of diamond surface with various carboxylic acids by radical reaction in liquid phase. Diamond and Related Materials. 2004;13:1093-1097. DOI:10.1016/j.diamond.2003.10.065

92. Cheng CY, Perevedentseva E, Tu JS, Chung PH, Cheng CL, Liu KK, Chao JI, Chen PH, Chang CC. Direct and in vitro observation of growth hormone receptor molecules in A549 human lung epithelial cells by nanodiamond labeling. Applied Physics Letters. 2007;90:163903. DOI:10.1063/1.2727557

93. Chung PH, Perevedentseva E, Tu JS, Chang CC, Cheng CL. Spectroscopic study of bio-functionalized nanodiamonds. Diamond and Related Materials. 2006;15:622-625. DOI:10.1016/j.diamond.2005.11.019

94. Krueger A, Liang YJ, Jarre G, Stegk J. Surface functionalization of detonation diamond suitable for biological applications. Journal of Materials Chemistry. 2006;16:2322-2328. DOI:10.1039/B601325B

95. Huang H, Pierstorff E, Osawa E, Ho D. Active nanodiamond hydrogels for chemotherapeutic delivery. Nano Letters. 2007;7(11):3305-3314. DOI:10.1021/n1071521o

96. Drummond TG, Hill MG, Barton JK. Electrochemical DND sensors. Nature Biotechnology. 2003;21:1192-1199. DOI:10.1038/nbt873
97. Lee Y-S, Mrksich M. Protein chips: from concept to practice. Trends in Biotechnology. 2002;20:s14-s18. DOI:10.1016/s1471-1931(02)00200-8

98. Zhu H, Snyder M. Protein chip technology. Current Opinion in Chemical Biology. 2003;7:55-63. DOI:10.1016/s1367-5931(02)00005-4

99. Fu C-C, Lee H-Y, Chen K, Lim T-S, Wu H-Y, Lin P-K, Tsao P-H, Chang H-C, Fann W. Characterization and application of single fluorescent nanodiamonds as cellular biomarkers. Proceedings of the National Academy of Sciences. 2007;104(3):727-732. DOI:10.1073/pnas.0605409104

100. Chang IP, Hwang KC, Chiang C-S. Preparation of fluorescent magnetic nanodiamonds and cellular imaging. Journal of the American Chemical Society. 2008;130(46):15476-15481. DOI:10.1021/ja804253y

101. Faklaris O, Garrot D, Joshi V, Boudou JP, Sauvage T, Curmi PA, Treussart F. Comparison of the photoluminescence properties of semiconductor quantum dots and non-blinking diamond nanoparticles and observation of the diffusion of diamond nanoparticles in living cells. Journal of the European Optical Society-Rapid Publications. Rap. 2009;4:09035. DOI:10.2971/jeos.2009.09035

102. Neu E, Agio M, Becher C. Photophysics of single silicon vacancy centers in diamond: implications for single photon emission. Optics Express. 2012;20:19956-19971. DOI:10.1364/OE.20.019956

103. Neugart F, Zappe A, Jelezko F, Tietz C, Boudou JP, Krueger A, Wrachtrup J. Dynamics of diamond nanoparticles in solution and cells. Nano Letters. 2007;7(12):3588-3591. DOI:10.1021/n10716303

104. Wang C, Kurtsiefer C, Weinfurter $\mathrm{H}$, Burchard B. Single photon emission from SiV centres in diamond produced by ion implantation. Journal of Physics B: Atomic, Molecular and Optical. 2006;39:37-41. DOI:10.1088/0953-4075/39/1/005

105. Girard HA, El-Kharbachi A, Garcia-Argote S, Petit T, Bergonzo P, Rousseau B, Arnault J-C. Tritium labeling of detonation nanodiamonds. Chemical Communications. 2014;50:2916-2918. DOI:10.1039/ $\mathrm{C} 3 \mathrm{CC} 49653 \mathrm{H}$

106. Huang H, Pierstorff E, Liu K, Osawa E, Ho D (ed.). Nanodiamond-mediated delivery of therapeutics via particle and thin film architectures. Nanodiamonds: applications in biology and nanoscale medicine. USA: Springer; 2010;7:151-174. DOI:10.1007/978-1-4419-0531-4

107. Chen Y-C, Lee D-C, Hsiao C-Y, Chung Y-F, Chen H-C, Thomas JP, Pong W-F, Tai N-H, Lin I-N, Chiu I-M. The effect of ultrananocrystalline diamond films on the proliferation and differentiation of neural stem cells. Biomaterials. 2009;30(20):3428-3435. DOI:10.1016/j.biomaterials.2009.03.058

108. Kazakov AG, Garashchenko BL, Yakovlev RYu, Vinokurov SE, Kalmykov SN, Myasoedov BF. An experimental study of sorption / desorption of 
selected radionuclides on carbon nanomaterials: a quest for possible applications in future nuclear medicine. Diamond and Related Materials. 2020;104:107752. DOI:10.1016/j.diamond.2020.107752

109. Zhang X, Yin J, Kang C, Li J, Zhu Y, Li W, Huang Q, Zhu Z. Biodistribution and toxicity of nanodiamonds in mice after intratracheal instillation. Toxicology Letters. 2010;198(2):237-243. DOI:10.1016/j.toxlet.2010.07.001

110. Yuan Y, Wang X, Jia G, Liu J-H, Wang T, Gu Y, Yang S-T, Zhen S, Wang H, Liu Y. Pulmonary toxicity and translocation of nanodiamond in mice. Diamond and Related Materials. 2010;19(4):291-299. DOI:10.1016/j.diamond.2009.11.022

111. Dolmatov VYu, Kostrova LN. Detonationsynthesized nanodiamonds and the feasibility to develop a new generation of medicines. Journal of Superhard Materials. 2000;3:79-82.

112. Liu K-K, Wang C-C, Cheng C-L, Chao J-I. Endocytic carboxylated nanodiamond for the labeling and tracking of cell division and differentiation in cancer and stem cells. Biomaterials. 2009;30(26):4249-4259. DOI:10.1016/j.biomaterials.2009.04.056

113. Vaijayanthimala V, Tzeng Y-K, Chang H-C, Li C-L. The biocompatibility of fluorescent nanodiamonds and their mechanism of cellular uptake. Nanotechnology. 2009;20(42):425103. DOI:10.1088/0957-4484/20/42/425103

114. Schrand AM, Huang H, Carlson C, Schlager JJ, Sawa EO, Hussain SM, Dai L. Are diamond nanoparticles cytotoxic? Journal of Chemical Physics $B$. 2007;111(1):2-7. DOI:10.1021/jp066387v

115. Karpukhin AV, Avkhacheva NV, Yakovlev RY, Kulakova II, Yashin VA, Lisichkin GV, Safronova VG. Effect of detonation nanodiamonds on phagocyte activity. Cell Biology International. 2011;35(7):727-733. DOI:10.1042/CBI20100548
116. Paget V, Sergent JA, Grall R, AltmeyerMorel S, Girard HA, Petit T, Gesset C, Mermoux M, Bergonzo P, Arnault JC, Chevillard S. Carboxylated nanodiamonds are neither cytotoxic nor genotoxic on liver, kidney, intestine and lung human cell lines. Nanotoxicology. 2014;8(1):46-56. DOI:10.3109/ 17435390.2013.855828

117. Alawdi SH, El-Denshary ES, Safar MM, Eidi H, David M-O, Abdel-Wahhab MA. Neuroprotective effect of nanodiamond in Alzheimer's disease rat model: a pivotal role for modulating NF- $\kappa \mathrm{B}$ and STAT3 signaling. Molecular Neurobiology. 2017;54(3):1906-1918. DOI:10.1007/s12035-016-9762-0

118. Dolmatov VYu. Ultrafine detonation synthesis diamonds. Obtaining, properties, application. St. Petersburg: Peter the Great St. Petersburg Polytechnic University Publ.; 2003. 343 p. (In Russ.)

119. Liao W-S, Ho Y, Lin Y-W, Raj EN, Liu K-K, Chen Ch, Zhou X-Z, Lu K-P, Chao J-I. Targeting EGFR of triple-negative breast cancer enhances the therapeutic efficacy of paclitaxel- and cetuximab-conjugated nanodiamond nanocomposite. Acta Biomaterialia. 2016;86(1):395-405. DOI:10.1016/j.actbio.2019.01.025

120. Zhao J, Lu M, Lai H, Lu H, Lalevee J, Barner-Kowollik Ch, Stenzel MH, Xiao P. Delivery of amonafide from fructose-coated nanodiamonds by oxime ligation for the Treatment of Human Breast Cancer. Biomacromolecules. 2018;19(2):481-489. DOI:10.1021/acs.biomac.7b01592

121. Dolmatov VYu. Biologically active ultrafine detonation synthesis diamonds. Russian Federation patent 2,203,068. 27 April 2003. (In Russ.)

122. Dolmatov VYu, Kostrova LN. Detonationsynthesized nanodiamonds and the posibility to develop a new generation of medicines. Journal of Superhard Materials. 2000;3:79-82.

\section{Информация об авторах / Information about the authors}

Долматов Валерий Юрьевич, доктор технических наук, начальник научно-исследовательской лаборатории, ФГУП «Специальное конструкторско-технологическое бюро «Технолог», Санкт-Петербург, Российская Федерация; ORCID 0000-0001-8643-0404; e-mail: diamondcentre@mail.ru

Шамес Александр Исаакович, Ph.D., старший исследователь, Университет им. Бен Гуриона в Негеве, Беэр-Шева, Израиль; ORCID 0000-0002-0574-1911; e-mail: sham@bgu.ac.il

Эйдзи Осава, профессор, президент, NanoCarbon Institute Co., Ltd., Японский национальный университет в префектуре Нагано, Уэда, Япония; ORCID 0000-00021147-0898; e-mail: osawa@nano-carbon.jp

Аско Веханен, Ph.D., директор, Carbodeon Ltd. Oy, Вантаа, Финляндия; AuthorID (Scopus) 6701383667; e-mail: asko.vehanen@carbodeon.com
Valerii Yu. Dolmatov, D. Sc. (Engineering), Head of research laboratory, Special Construction and Technology Bureau "Technolog", St. Petersburg, Russian Federation; ORCID 0000-0001-8643-0404; e-mail: diamondcentre@mail.ru

Alexander I. Shames, Ph.D., Senior Researcher, Ben-Gurion University of the Negev, Beer-Sheva, Israel; ORCID 0000-0002-0574-1911; e-mail: sham@bgu.ac.il

Eiji Ōsawa, Professor, President of NanoCarbon Research Institute Limited, Shinshu University, Ueda, Japan; ORCID 0000-0002-1147-0898; e-mail: osawa@nano-carbon.jp

Asko Vehanen, Ph.D., Director, Carbodeon Ltd. Oy, Vantaa, Finland; AuthorID (Scopus) 6701383667; e-mail: asko.vehanen@carbodeon.com 
Веса Мюллюмяки, Ph.D., главный исполнительный директор, Carbodeon Ltd. Оу, Вантаа, Финляндия; AuthorID (Scopus) 55627561500; e-mail: vesa.myllymaki@carbodeon.fi

Дорохов Александр Олегович, главный инженер, АО «Завод «Пластмасс» Копейск, Российская Федерация; AuthorID (Scopus) 57209505072; e-mail: aldor7174@icloud.com

Марчуков Валерий Александрович, кандидат химических наук, ведущий инженер-конструктор, ФГУП «Специальное конструкторско-технологическое бюро «Технолог», Санкт-Петербург, Российская Федерация; AuthorID (Scopus) 7801670746; e-mail: marvalal@yandex.ru

Козлов Анатолий Сергеевич, кандидат химических наук, начальник НПК-2, ФГУП «Специальное конструкторско-технологическое бюро «Технолог», Санкт-Петербург, Российская Федерация; AuthorID (Scopus) 7402290001; e-mail: too1999@yandex.ru

Нарыжный Сергей Юрьевич, инженер-конструктор 1 категории, ФГУП «Специальное конструкторскотехнологическое бюро «Технолог», Санкт-Петербург, Российская Федерация; e-mail: sergei.nar@bk.ru

Смирнова Анастасия Захаровна, инженер-исследователь 3 категории, ФГУП «Специальное конструкторско-технологическое бюро «Технолог», Санкт-Петербург, Российская Федерация; e-mail: 1nasty5smir1@mail.ru
Vesa Myllymäki, Ph.D., CEO, Carbodeon Ltd. Oy, Vantaa, Finland; AuthorID (Scopus) 55627561500; e-mail: vesa.myllymaki@carbodeon.fi

Alexander O. Dorokhov, Chief Engineer, JSC "Plant" Plastics", Kopeysk, Russian Federation; AuthorID (Scopus) 57209505072; e-mail: aldor7174@icloud.com

Valerii A. Marchukov, Cand. Sc. (Chemistry), Leading Design Engineer, Special Construction and Technology Bureau "Technolog", St. Petersburg, Russian Federation; AuthorID (Scopus) 7801670746; e-mail: marvalal@yandex.ru

Anatoly S. Kozlov, Cand. Sc. (Chemistry), Head of NPK-2, Special Construction and Technology Bureau "Technolog", St. Petersburg, Russian Federation; AuthorID (Scopus) 7402290001; e-mail: too1999@yandex.ru

Sergey Yu. Naryzhny, $1^{\text {cat. }}$ Design Engineer, Special Construction and Technology Bureau "Technolog", St. Petersburg, Russian Federation; e-mail: sergei.nar@bk.ru

Anastasia Z. Smirnova, $3^{\text {cat. }}$ Research Engineer, Special Construction and Technology Bureau "Technolog", St. Petersburg, Russian Federation; e-mail: 1nasty5smir1@mail.ru

Received 13 January 2021; Accepted 26 February 2021; Published 21 April 2021

Copyright: (C) Dolmatov VYu, Shames AI, Ōsawa E, Vehanen A, Myllymäki V, Dorokhov AO, Martchukov VA,
Kozlov AC, Naryzhny SYu, Smirnova AZ, 2021. This article is an open access article distributed under the
terms and conditions of the Creative Commons Attribution (CC BY) license
(https://creativecommons.org/licenses/by/4.0/).

Территория распространения - Российская Федерация, зарубежные страны. Distributed is the Russian Federation and foreign countries.

Оригинал-макет подготовлен в Издательском центре ФГБОУ ВО «ТГТУ», 392032, Тамбовская обл., г. Тамбов, ул. Мичуринская, д. 112А

Подписано в печать 31.03.2021. Дата выхода в свет 21.04.2021

Формат 60×90/8. Усл. печ. л. 10,0. Уч.-изд. л. 10,32. Тираж 100 экз. Цена свободная. Заказ № 016. СМИ журнал "Јournal of Advanced Materials and Technologies"

(Журнал современных материалов и технологий) выпуск 2021. Том 6, № 1.

Материалы журнала доступны по лицензии Creative Commons “Attribution” («Атрибуция») 4.0 Всемирная (СС ВY 4.0)

All the materials of the "Golden Horde Review" are available under the Creative Commons License "Attribution" 4.0 International (CC BY 4.0)

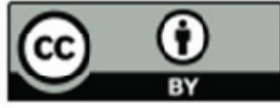

